\title{
Angicin, a novel bacteriocin of Streptococcus anginosus
}

Vogel, Verena; Bauer, Richard; Mauerer, Stefanie; Schiffelholz, Nicole; Haupt, Christian; Seibold, Gerd M.; Fändrich, Marcus; Walther, Paul; Spellerberg, Barbara

Published in:

Scientific Reports

Link to article, DOI:

$10.1038 / \mathrm{s} 41598-021-03797-5$

Publication date:

2021

Document Version

Publisher's PDF, also known as Version of record

Link back to DTU Orbit

Citation (APA):

Vogel, V., Bauer, R., Mauerer, S., Schiffelholz, N., Haupt, C., Seibold, G. M., Fändrich, M., Walther, P., \& Spellerberg, B. (2021). Angicin, a novel bacteriocin of Streptococcus anginosus. Scientific Reports, 11, [24377]. https://doi.org/10.1038/s41598-021-03797-5

\section{General rights}

Copyright and moral rights for the publications made accessible in the public portal are retained by the authors and/or other copyright owners and it is a condition of accessing publications that users recognise and abide by the legal requirements associated with these rights.

- Users may download and print one copy of any publication from the public portal for the purpose of private study or research.

- You may not further distribute the material or use it for any profit-making activity or commercial gain

- You may freely distribute the URL identifying the publication in the public portal 


\title{
scientific reports
}

Check for updates

\section{Angicin, a novel bacteriocin of Streptococcus anginosus}

\author{
Verena Vogel ${ }^{1}$, Richard Bauer ${ }^{1}$, Stefanie Mauerer ${ }^{1}$, Nicole Schiffelholz ${ }^{2}$, Christian Haupt ${ }^{2}$, \\ Gerd M. Seibold ${ }^{3}$, Marcus Fändrich², Paul Walther ${ }^{4}$ \& Barbara Spellerberg ${ }^{1 \bowtie}$
}

As a conserved defense mechanism, many bacteria produce antimicrobial peptides, called bacteriocins, which provide a colonization advantage in a multispecies environment. Here the first bacteriocin of Streptococcus anginosus, designated Angicin, is described. S. anginosus is commonly described as a commensal, however it also possesses a high pathogenic potential. Therefore, understanding factors contributing to its host colonization and persistence are important. A radial diffusion assay was used to identify S. anginosus BSU 1211 as a potent bacteriocin producer. By genetic mutagenesis the background of bacteriocin production and the bacteriocin gene itself were identified. Synthetic Angicin shows high activity against closely related streptococci, listeria and vancomycin resistant enterococci. It has a fast mechanism of action and causes a membrane disruption in target cells. Angicin, present in cell free supernatant, is insensitive to changes in temperature from -70 to $90^{\circ} \mathrm{C}$ and $\mathrm{pH}$ values from 2 to 10 , suggesting that it represents an interesting compound for potential applications in food preservation or clinical settings.

Streptococcus anginosus is commonly regarded as a commensal of mucosal membranes. Together with Streptococcus constellatus and Streptococcus intermedius it forms the Streptococcus anginosus Group (SAG), which belongs to the viridians streptococci. It is found in the oral cavity, the gastrointestinal and the urogenital tracts ${ }^{1,2}$. However, increasing evidence points to the pathogenic potential of $S$. anginosus. The incidence rate of $(8.65 / 100.000)$ of invasive SAG infections is higher than Group A and B streptococci (4.3 and 3.1/100,000 population) combined ${ }^{3,4}$. The species $S$. anginosus can cause severe purulent infections at all body sites in particular cranial infections ${ }^{4}$. Furthermore, isolation has been reported from invasive infections, abscesses, urine, blood cultures and cystic fibrosis patients ${ }^{3,5-8}$.

In a natural environment, bacteria are part of multispecies communities, where space and nutrients are a limiting factor ${ }^{9}$. For efficient host colonization, it is important for bacteria to outcompete rival species. A mechanism for dealing with competing species is bacteriocin production. Bacteriocins are small antimicrobial peptides produced by bacteria to inhibit the growth of other, often closely related, bacteria ${ }^{10,11}$. These cationic peptides are ribosomally produced and either undergo major (class I) or nearly no post translational modification (class II). Class I and II bacteriocins are characterized by being thermostable and by possessing a molecular mass of less than $10 \mathrm{kDa}$. The main mechanism of action is the disruption of cell wall and membrane integrity of target species. Bacteriocin producers are rendered insensitive towards their own bacteriocin by simultaneous expression of immunity proteins. Bacteriocin production is often regulated via quorum sensing (QS) mechanisms ${ }^{12-15}$. QS is a cell density dependent regulation of gene expression.

It is a common trait of lactic acid bacteria to produce bacteriocins, and several streptococcal bacteriocins have been described ${ }^{16-18}$. For several streptococci bacteriocin production is not only important for intra- and interspecies competition but also for the acquisition of extracellular DNA. In Streptococcus pneumoniae and Streptococcus salivarius bacteriocin production is coupled to competence ${ }^{19,20}$. By killing target organisms, DNA is released into the extracellular environment and subsequently taken up by the competence machinery. Similar to S. pneumoniae and S. salivarius, S. anginosus is naturally competent ${ }^{21}$. Bacteriocins have been shown to recognize and bind to specific membrane receptors and thereby facilitating the killing of target cells. For several class II bacteriocins the mannose-phosphotransferase system (Man-PTS) was identified as receptor ${ }^{22-24}$.

So far, bacteriocin production of $S$. anginosus has not been analyzed in detail. Mendonca et al. investigated the regulation of a putative bacteriocin in Streptococcus intermedius ${ }^{12}$. In this species the Streptococcal invasion locus (sil), has been shown to act as a regulator for bacteriocin production ${ }^{12,25,26}$. The sil locus encodes a QS system consisting of a two-component system (SilA/B), a signaling peptide (SilCR) and an export/processing system

${ }^{1}$ Institute of Medical Microbiology and Hygiene, Ulm University Medical Center, Ulm, Germany. ${ }^{2}$ Institute of Protein Biochemistry, Ulm University, Ulm, Germany. ${ }^{3}$ Department of Biotechnology and Biomedicine, Technical University of Denmark, Kongens Lyngby, Denmark. ${ }^{4}$ Central Facility for Electron Microscopy, Ulm University, Ulm, Germany. ${ }^{\boxplus}$ email: barbara.spellerberg@uniklinik-ulm.de 


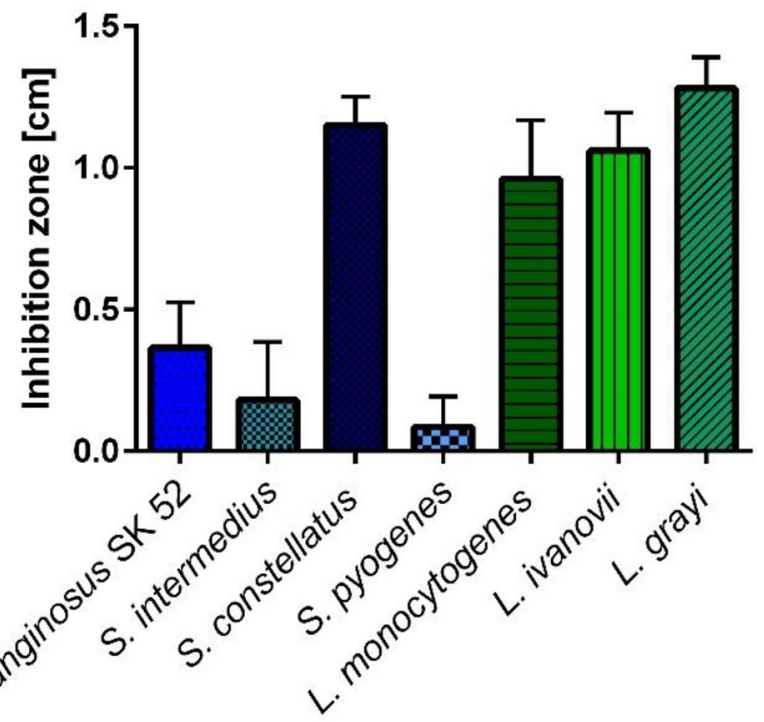

Target strain

Figure 1. Spectrum of activity of S. anginosus BSU 1211. In a one-layer radial diffusion assay (RDA) $S$. anginosus BSU 1211 was tested for an effect against several target species. S. anginosus BSU 1211 shows activity against oral streptococci and several listeria species. Depicted is the mean \pm standard deviation of at least five experiments.

(SilD/E). In S. intermedius the putative bacteriocin production was reported to be induced by the addition of SilCR, but the bacteriocin itself has not been characterized experimentally. However, even though similar genes are present in S. anginosus neither bacteriocin production nor the sil locus has been investigated in this species.

To study the bacteriocin production of S. anginosus, we screened multiple $S$. anginosus strains for their ability to inhibit closely related bacterial species. Through targeted mutations, the genetic background for bacteriocin production of $S$. anginosus was identified. The novel bacteriocin was designated as Angicin and phenotypic traits like spectrum of activity, sensitivity towards heat, $\mathrm{pH}$ and enzymes as well as the mechanisms of inducing bacteriocin production are elucidated.

\section{Results}

Isolation of the bacteriocin producing S. anginosus strain BSU 1211. Producing bacteriocins is a common trait of streptococci. Screening 95 clinical Streptococcus anginosus isolates for strains inhibiting the growth of the closely related streptococcal species Streptococcus anginosus SK 52, Streptococcus constellatus, Streptococcus intermedius and Streptococcus pyogenes (Supplementary Table S1) led to the identification of the strain S. anginosus BSU 1211. Out of the 95 clinical S. anginosus isolates 44 (46\%) were able to inhibit at least one of these streptococcal indicator strains, while strain BSU 1211 appears to be a potent bacteriocin producer that was active against multiple species and caused the biggest inhibition zone of all strains. When tested in a onelayer radial diffusion assay (RDA) it shows activity against the S. anginosus type strain SK52 and other streptococci like S. constellatus, S. intermedius and S. pyogenes (Fig. 1). In addition, the pathogen Listeria monocytogenes as well as other listerial species like Listeria ivanovii and Listeria grayi are strongly inhibited by S. anginosus BSU 1211 (Fig. 1). However, for both L. monocytogenes and L. ivanovii sometimes colonies could be seen in the inhibition zones.

Subsequently, the clinically relevant ESKAPE pathogens, consisting of Enterococcus faecium, Staphylococcus aureus, Klebsiella pneumoniae, Acinetobacter baumannii and Pseudomonas aeruginosa were investigated for a susceptibility towards bacteriocins of S. anginosus BSU 1211. These species cause nosocomial infections and are associated with high mortality ${ }^{27,28}$. However, no activity against any of these strains was seen. Additionally, neither staphylococci (Staphylococcus aures, Staphylococcus epidermidis), lactobacilli (Lactobacillus gasseri, Lactobacillus acidophilus, Lactobacillus paracasei, Lactobacillus rhamnosus, Lactobacillus casei), other streptococci (Streptococcus agalactiae, Streptococcus mutans, Streptococcus dysagalactiae subsp. equisimilis, Streptococcus suis, Streptococcus porcinus, Streptococcus pneumoniae, Streptococcus mitis, Streptococcus oralis), Escherichia coli nor Bacillus subtilis were inhibited by S. anginosus BSU1211.

Genetic background of bacteriocin production. To identify genes responsible for bacteriocin production in S. anginosus BSU 1211 the sil locus and the surrounding regions of the genome were sequenced. In S. intermedius and other species of the SAG, a putative bacteriocin encoding region is adjacent to the quorum sensing locus sil ${ }^{12}$. We found that all sil genes are present in S. anginosus BSU 1211 and that an adjacent region is present, resembling the putative bacteriocin accessory region described in Mendonca et al. (Fig. 2). The open reading frames (ORF) were designated bacteriocin like peptide3 (blp3) in accordance with similar findings in 


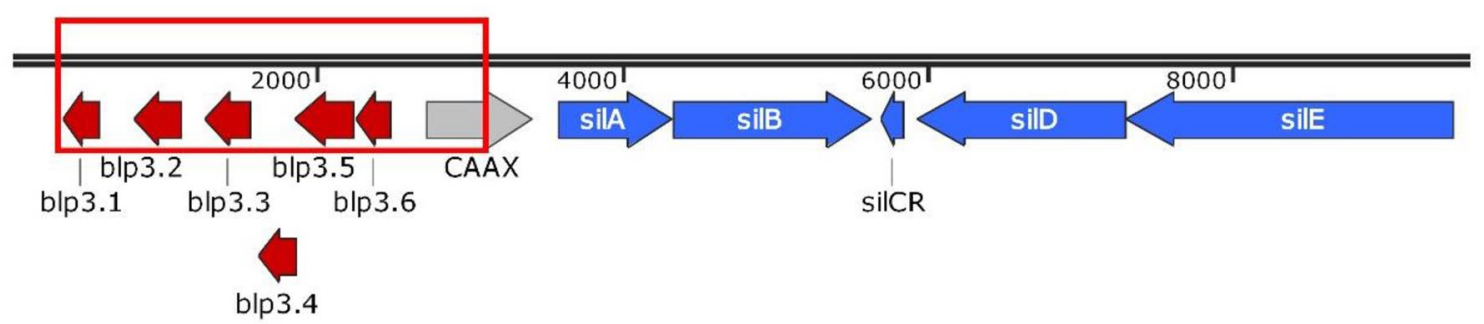

Figure 2. Genetic organization of S. anginosus BSU 1211. The sil genes and the $b l p 3$ region were sequenced and open reading frames were adapted from Mendonca et al. and labeling was done in line with Hertzog et al. ${ }^{12,17}$. $B l p 3.1, b l p 3.4$ and $b l p 3.6$ are predicted as putative bacteriocins. Blp3.3 and $b l p 3.5$ were predicted as putative immunity proteins. SilA, silB, silCR, silD and silE form a quorum sensing system. In red the deleted region of $S$. anginosus BSU $1211 \Delta \mathrm{blp} 3$ is demonstrated. Schematic overview was constructed with SnapGene.

\begin{tabular}{|l|l|l|}
\hline & Bagle4 & BlastX (query/identitiy) \\
\hline Blp3.1 & BlpU & Bacteriocin [S. anginosus] (98\%/100\%) \\
\hline Blp3.2 & No function determined & Hypothetical protein [S. anginosus] (99\%/99\%) \\
\hline Blp3.3 & Putative piscicolin 126 immunity protein, PisI & Bacteriocin immunity protein [S. anginosus] (98\%/100\%) \\
\hline Blp3.4 & Bovicin variant 255 & $\begin{array}{l}\text { MULTISPECIES: Garvicin Q family class II bacteriocin [Streptococcus] (90\%/ } \\
100 \%)\end{array}$ \\
\hline Blp3.5 & Bacteriocin self-immunity, putative & Hypothetical protein SII_1169 [S. intermedius C270] (98\%/100\%) \\
\hline Blp3.6 & BlpU & MULTISPECIES: bacteriocin [Streptococcus] (98\%/100\%) \\
\hline CAAX & No function determined & $\begin{array}{l}\text { MULTISPECIES: CPBP family intramembrane metalloprotease [Streptococcus] } \\
\text { (99\%/99.95\%) }\end{array}$ \\
\hline
\end{tabular}

Table 1. Bioinformatic analysis of $b l p 3$ region.

S. pyogenes (Hertzog et al., 2018.). Bioinformatic analysis of the genes in this region with BLAST (https://blast. ncbi.nlm.nih.gov/Blast.cgi) and Bagel4 (http://bagel4.molgenrug.nl/) predicted three putative class II bacteriocins $(b l p 3.1$, blp3.4, blp3.6) (Table 1). By Bagel4 core peptide analysis, the proteins encoded by blp3.1 (MKTKTLEKFEVLNSEMLARVEGGGCNWGDFAKSGIAGGAGNRLRLGIKTITWQGVVAGAVGGAIIGKVGYG ATCWW) and blp3.6 (MNTKSLEKFEVLNSEMLASVEGGKIGAGEAAQALAVCTVAGGTIGSVFPGVGTAVGAILGAQYCTGAWAIIRAH) resemble the known bacteriocin BlpU (Table 1). Both contain GxxxG motifs, which are a hallmark for two peptide bacteriocins ${ }^{29}$. A high homology to the Bovicin variant 255 and Garvicin $\mathrm{Q}$ is found for Angicin (MKESENFMLNLKGEVVNELSDVQLSEISGGGSGYCKPVMVGANGYACRYSNGRWDYKVTKGIFQATTDVIVKGWAEYGPWIPRH) (encoded by $b l p 3.4$ ). The finding that $b l p 3.1, b l p 3.4$ and blp3.6 all encode a leader peptide with a double glycine motif, further supports the theory of these peptides being putative bacteriocins. All other deduced proteins did not match any of the known bacteriocin. Further sequence analysis with Bagel4 predicted $b l p 3.3$ and $b l p 3.5$ to encode immunity proteins. For $b l p 3.2$ no hypothetical function could be determined, while CAAX showed high similarities (99\%) to the CPBP family of intramembrane metalloprotease in BLAST analysis.

The blp3-region could be identified in some completely sequence S. anginosus isolates (J4211, C1051, MAS624, C238, FDAARGOS_1155, FDAARGOS_1357) as well as in several other clinical S. anginosus isolates (BSU 1326, BSU 1370, BSU 1401). The blp3-regions of S. anginosus J4211, C1051, BSU 1370 and BSU 1401 contain the same genes and are $99 \%$ identical with strain BSU 1211. Blp3.1 of S. anginosus J4211, C1051, BSU 1326 and BSU 1401 has one mutation (R42G) when compared to Blp3.1 of S. anginosus BSU 1211, while the deduced peptide sequence of $b l p 3.4$ and $b l p 3.6$ is identical in all analyzed strains.

The putative regulatory sil locus of $S$. anginosus BSU 1211 appears to be conserved in S. anginosus strains. The genes silA, silD and silE are identical to the respective genes described in the whole genomes sequence of S. anginosus_1_2_62CV. Furthermore, silB shows $99.85 \%$ and silCR $99.32 \%$ sequence identity. However, a point mutation was found in silCR leading to an amino acid change (F11L) in the mature autoinducing peptide SilCR,

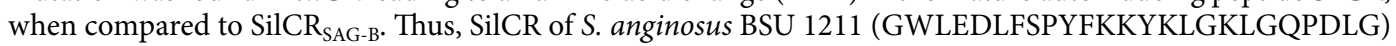
is labeled SilCR $\mathrm{SAG}-\mathrm{C}_{\text {. }}$

Regulation and induction of bacteriocin production. Even though the strains BSU 1326, 1370 and 1401 encode the same bacteriocins as S. anginosus BSU 1211 no or only moderate inhibition of target strains can be observed in a one-layer RDA (Fig. 3). To investigate if bacteriocin production in these strains is dependent on the sil locus, synthetic autoinducing peptide SilCR was added in a one-layer RDA. Inhibition zones increase as soon as SilCR SAG-C $_{\text {is administered to the bacterial culture (Fig. 3). Without the addition of SilCR }}$ SAG-C $S$. anginosus BSU 1326 and 1370 are not able to inhibit any target strains. For S. anginosus BSU 1326 inhibition zones with a diameter of $0.36 \mathrm{~cm}$ for $S$. constellatus and $0.47 \mathrm{~cm}$ for L. monocytogenes were observed in the presence of

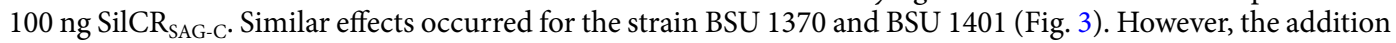




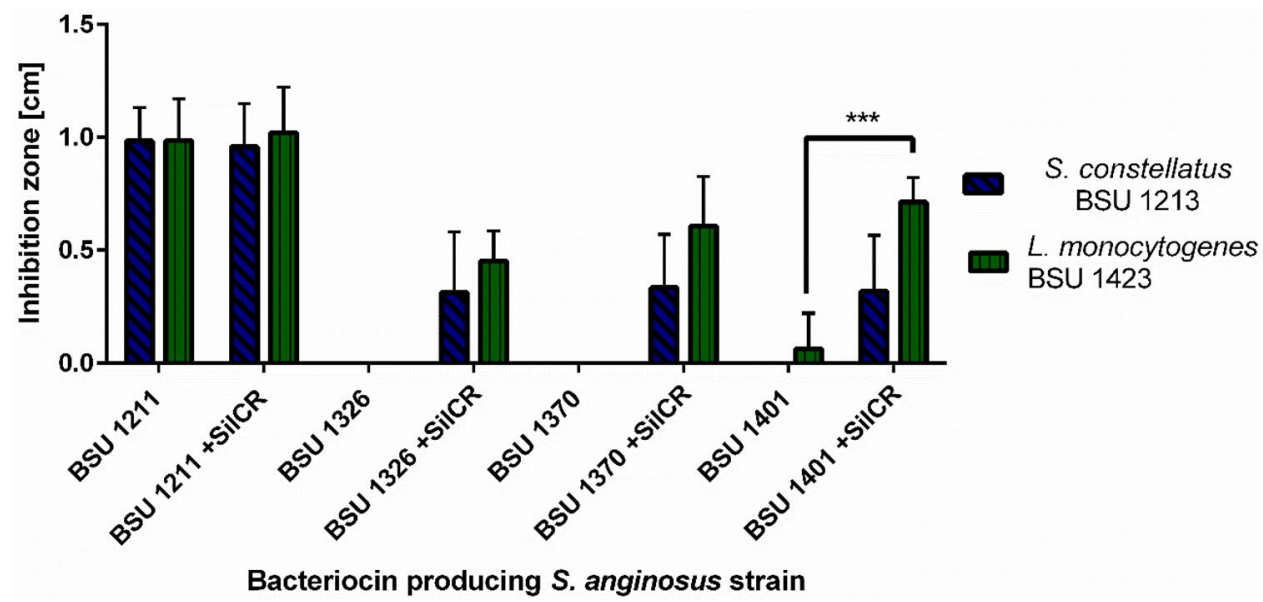

Figure 3. Induction of Angicin production by addition of $\mathrm{SilCR}_{\mathrm{SAG}-\mathrm{C}}$. Result of a one-layer radial diffusion assay. S. constellatus BSU 1213 and L. monocytogenes BSU 1423 were used as target strains. The inhibitory activity of S. anginosus BSU 1211, 1326, 1370 and 1401 was determined either in the presence or absence of $100 \mathrm{ng}$ SilCR $\mathrm{SAG}_{\mathrm{C}}$. Depicted is mean \pm standard deviation of at least five independent experiments. A significant difference between SilCR SAG-C $_{\text {s }}$ supplemented and untreated $S$. anginosus strains was tested with a MannWhitney-U-test $\left({ }^{* *} \mathrm{p}<0.001\right)$.

a

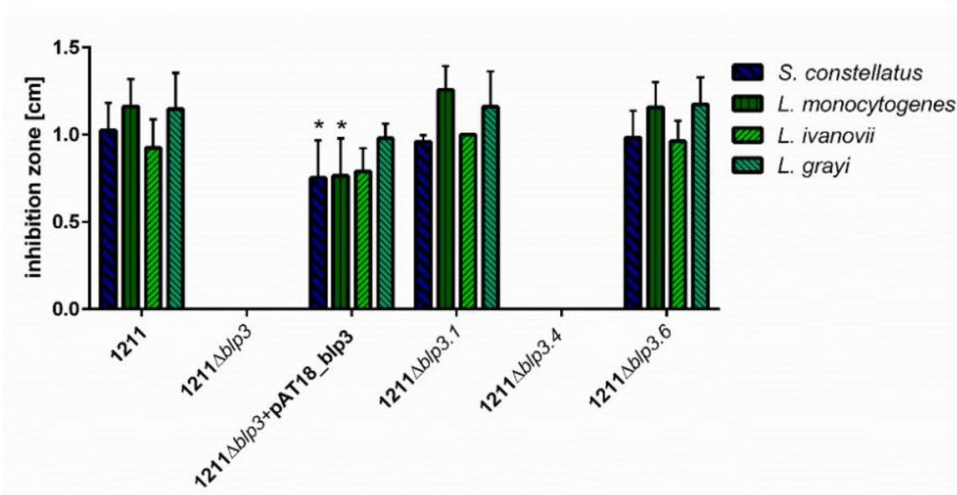

b

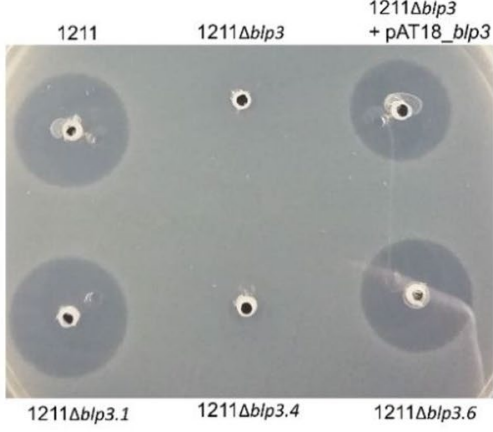

Figure 4. Inhibition of target strains by blp3-region mutants. (a) The effect of completely deleting $b l p 3$ or only deleting the predicted bacteriocin genes was tested in a one-layer radial diffusion assay against the four most prominent target strains S. constellatus, L. monocytogenes, L. grayi, and L. ivanovii. Furthermore, a S. anginosus BSU $1211 \Delta b l p 3$ was complemented with the blp3-region encoded on plasmid pAT18. The complementation mutant was supplemented with $100 \mathrm{ng}$ SilCR $_{\mathrm{SAG}-\mathrm{C}}$. Shown is the mean \pm standard deviation of at least five independent experiments. Significant differences between mutant and wildtype strain were calculated with a Mann-Whitney-U-test $\left({ }^{*} \mathrm{p}<0.05\right)$. (b) Result of a one-layer RDA against L. grayi.

of SilCR $\mathrm{SAG}_{\mathrm{S}}$ did not lead to larger inhibition zones for S. anginosus BSU1211, suggesting that maximal bacteriocin expression is already present in this strain. It is possible that in strain BSU 1211 bacteriocins are expressed constitutively. The autoinducing peptide $\mathrm{SilCR}_{\mathrm{SAG}-\mathrm{C}}$ alone did not cause any inhibition of target strains.

The blp3 region. Often all genes necessary for bacteriocin production are clustered in one genetic region. To verify that in S. anginosus BSU 1211 the blp3-region is indeed responsible for the bacteriocin production and thereby the inhibition of target strains, a deletion mutant comprising the entire blp3 region was constructed (S. anginosus BSU 1211 $\Delta$ blp3) (Fig. 2). S. anginosus BSU 1211 $\Delta$ blp3 failed to inhibit any strain that was sensitive towards $S$. anginosus BSU 1211. The inhibition of these strains could be reestablished by complementing S. anginosus BSU $1211 \Delta b l p 3$ with a plasmid (pAT18-blp3) that encoded the deleted blp3 region. Maximum activity of the complementation mutant against L. monocytogenes, L. grayi or L. ivanovii could be observed with

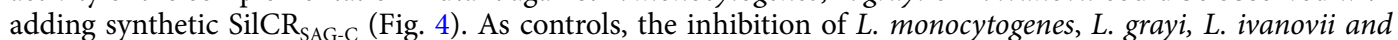
S. constellatus by $S$. anginosus SK52 (a strain which lacks the sil and blp3 region) transformed with pAT18-blp3 and S. anginosus BSU $1211 \Delta b l p 3$ transformed with the empty plasmid was investigated. Neither one of these control strains showed an inhibition of target strains. This data clearly shows that the sil as well as the $b l p 3$ region are necessary for bacteriocin production, however the question arises which of the predicted bacteriocins is 
a

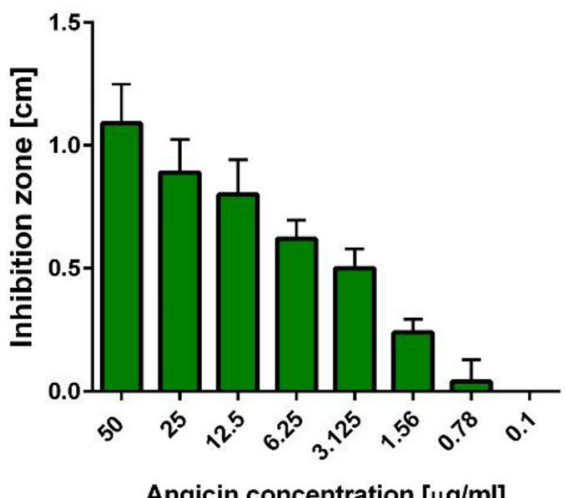

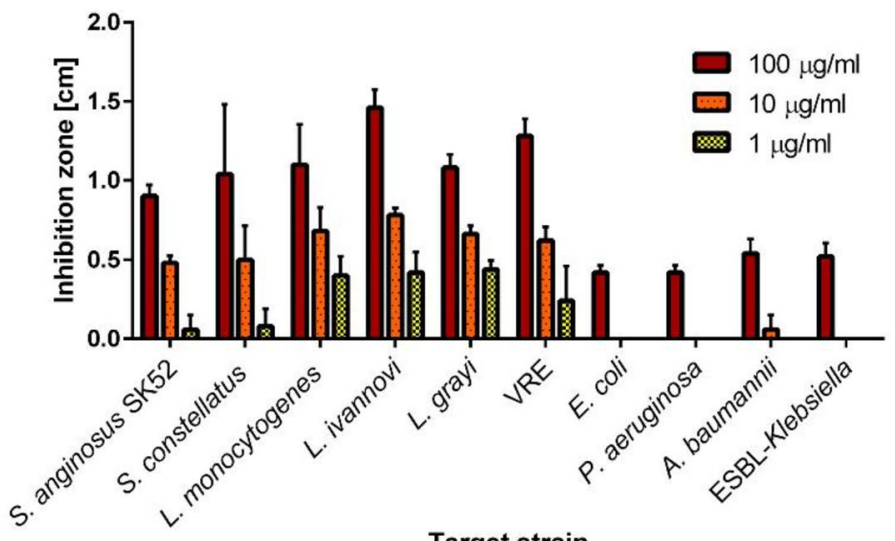

Target strain

Figure 5. Effect of synthesized angicin on target strains. (a) Different Angicin concentrations were tested for activity against L. monocytogenes in a two-layer RDA. (b) Angicin concentrations of 100,10 and $1 \mu \mathrm{g} / \mathrm{ml}$ were tested against different bacterial species in a two-layer RDA. $6.05 \mu \mathrm{g} / \mathrm{ml}$ equal $1 \mu \mathrm{M}$ Angicin. VRE indicates Vancomycin resistant Enterococcus faecium, ESBL is an abbreviation for extended spectrum beta-lactamase. Shown is the mean \pm standard deviation of five independent experiments.

functional and responsible for the activity or if more than one bacteriocin is produced and active, like it is the case in other streptococci $i^{30,31}$ or if the observed activity arises from synergistic effects of encoded peptides as described for Garvicin KS of Lactococcus garvieae ${ }^{32}$. To investigate this, single putative bacteriocin genes (blp 3.1, blp3.4 and blp3.6) were chromosomally deleted and subsequently these mutant strains were assessed for their ability to inhibit the four most prominent target strains (L. monocytogenes, L. ivanovii, L. grayi, S. constellatus). Deleting blp3.4 caused a complete loss of inhibition activity (Fig. 4). Unfortunately, BSU $1211 \Delta b l p 3.1$ contained an additional point mutation in the non-coding area between $b l p 3.1$ and $b l p 3.2$. However, it is not suspected that this mutation has any influence on bacteriocin production. A deletion of blp3.1 and blp3.6 did not alter antimicrobial activity. Thus, we conclude that Blp3.4, subsequently labeled Angicin, is the bacteriocin responsible for the antimicrobial activity of S. anginosus BSU 1211. By PCR analysis the blp3.4 gene was found in $41 \%$ (38 of 92) S. anginosus strains.

Angicin activity. Angicin is produced as an 84 amino acid long prepeptide. Typically, class II bacteriocins possess a leader peptide, which is cleaved off during export, resulting in the mature and active peptide. The first 30 amino acids of the 84 amino acid long prepeptide form a double glycine leader peptide which after processing leads to the 54 aa long mature Angicin. The peptide sequence of Angicin was compared to similar bacteriocins, like Bovicin 255, Garvicin Q and BacSJ. While Bovicin variant 255 has a sequence identity of approximately $64 \%$, Garvicin Q and BacSJ only have approximately $42 \%$ sequence identity (Supplementary Fig. S1). To verify that Angicin is accountable for the antimicrobial activity of S. anginosus BSU 1211 it was chemically synthesized. Angicin was synthesized without its respective leader peptide and without any post translational modifications. The experimental mass of synthetic Angicin was $6053.1 \mathrm{Da}$, as determined by mass spectrometry, closely matching the theoretic mass of this 54 amino acid peptide $(6052.9 \mathrm{Da})$. The isoelectric point of the peptide was determined at 10.2 by PSL Heidelberg, while computational analysis of the amino acid sequence with Bachem gave an isoelectric point at 9.6 and a net charge of 4 at neutral $\mathrm{pH}$ (https://www.bachem.com/service-support/ peptide-calculator/). The synthetic peptide was dissolved in ultra-pure water, and its activity was examined in a two-layer RDA against L. monocytogenes. Concentrations of $50 \mu \mathrm{g} / \mathrm{ml}$ Angicin caused an inhibition zone of $1.09 \pm 0.16 \mathrm{~cm}$, and even concentrations of $1.56 \mu \mathrm{g} / \mathrm{ml}$ Angicin were still able to inhibit growth of L. monocytogenes (Fig. 5a). This value corresponds well to a MIC determination of $3.125 \mu \mathrm{g} / \mathrm{ml}$ against L. monocytogenes and L. grayi (Supplementary Table S2). We then tested as to whether or not Angicin shows the same spectrum of activity as the strain S. anginosus BSU 1211. Based on a two-layer RDA (Fig. 5b) we find that strains of L. monocytogenes, L. grayi, L. ivanovii and S. constellatus, which are susceptible towards S. anginosus BSU1211 (Fig. 1), are also sensitive towards Angicin. However, the inhibition zones of $S$. constellatus were not completely clear in all experiments. S. anginosus SK52 showed a similar inhibition zone size like S. constellatus. In a second step, we investigated the Angicin susceptibility of a wide range of bacterial species including ESKAPE pathogens. We find that some of these pathogens, such as $S$. aureus, B. subtilis, are completely insensitive towards Angicin, while others showed a moderate inhibition at Angicin concentrations of $100 \mu \mathrm{g} / \mathrm{ml}$ (E. coli, K. pneumoniae, P. aeruginosa, A. baumannii). Interestingly, among these Angicin-sensitive ESKAPE pathogens was Enterococcus faecium (vancomycin resistant, VRE), which causes nosocomial infections and poses a huge health concern due to rising numbers and limited treatment options ${ }^{33}$. The tested VRE strain was as sensitive in our assay as the listeria species. 


\begin{tabular}{|c|c|c|}
\hline Treatment & Activity CFS & Activity angicin \\
\hline \multicolumn{3}{|l|}{ Temperature } \\
\hline $60^{\circ} \mathrm{C}-1 \mathrm{~h}$ & + & + \\
\hline $80^{\circ} \mathrm{C}-1 \mathrm{~h}$ & Reduced & + \\
\hline $90^{\circ} \mathrm{C}-1 \mathrm{~h}$ & Reduced & + \\
\hline $100^{\circ} \mathrm{C}-30 \mathrm{~min}$ & - & ND \\
\hline \multicolumn{3}{|l|}{$\mathrm{pH}$} \\
\hline 2 & + & ND \\
\hline 4 & + & ND \\
\hline 6 & + & ND \\
\hline 8 & + & ND \\
\hline 10 & + & ND \\
\hline 12 & - & ND \\
\hline \multicolumn{3}{|l|}{ Proteinase K } \\
\hline $1 \mathrm{mg} / \mathrm{ml}$ & - & - \\
\hline \multicolumn{3}{|l|}{ Lipase } \\
\hline $1 \mathrm{mg} / \mathrm{ml}$ & + & + \\
\hline \multicolumn{3}{|c|}{ Stability after 1 year } \\
\hline$-20^{\circ} \mathrm{C}$ & + & ND \\
\hline$-70^{\circ} \mathrm{C}$ & + & ND \\
\hline
\end{tabular}

Table 2. Bacteriocin stability in cell free supernatant against L. monocytogenes after various treatments. “+” indicates no altered activity, "reduced" indicates reduced activity and "-" means a complete loss of activity, ND indicates not determined.

Activity of cell free supernatant. Many bacteriocins are secreted into the culture supernatant. To better understand the physical and chemical properties of Angicin, cell free supernatant (CFS) of BSU 1211 was prepared. A two-layer RDA was carried out to assess the activity of CFS in comparison to the bacteriocin activity of bacterial cells from BSU 1211. In these experiments the previously identified target strain L. monocytogenes showed sensitivity towards CFS (Supplementary Fig. S2). However, no clear inhibition zone was observed. To show that Angicin is indeed the active component in CFS of BSU 1211, CFS of S. anginosus BSU 1211 $\Delta$ blp 3.4 was prepared and tested for activity. It showed no antimicrobial activity against $L$. monocytogenes. In a next step, the activity of CFS of BSU 1211 after exposure to heat or $\mathrm{pH}$ - changes was investigated. Results are summarized in Table 2 and demonstrate that the S. anginosus CSF can tolerate up to $1 \mathrm{~h}$ of $60^{\circ} \mathrm{C}$, an acidic $\mathrm{pH}$ of 2 , and can be kept at $-20^{\circ} \mathrm{C}$ and $-70^{\circ} \mathrm{C}$ for one year without loss of activity. However, exposure to $100^{\circ} \mathrm{C}$ for 30 min as well as treatment with proteinase $\mathrm{K}$ destroyed the bacteriocin activity of CFS. A treatment with lipase had no effect on CFS activity. As a control, CFS of $S$. anginosus BSU $1211 \Delta$ blp3 was challenged with the same treatments, but no inhibition of target strains was observed with BSU $1211 \Delta b l p 3$ CFS. We could show that synthetic Angicin resembled the activity pattern of BSU 1211 CFS when exposed to the above-mentioned heat challenges and enzyme treatments. In contrast to BSU $1211 \mathrm{CFS}$, however, we find that synthetic Angicin caused clear inhibition zones of L. monocytogenes and it showed no reduced activity upon heating at $90^{\circ} \mathrm{C}$ for $1 \mathrm{~h}$.

To investigate, if the Angicin activity of CFS can also be demonstrated in liquid culture experiments, we measured the growth of $L$. monocytogenes in the presence of $25 \%$ CFS (Supplementary Fig. S3). We find that $L$. monocytogenes is significantly inhibited in the presence of 25\% CFS from the wildtype strain BSU 1211 (p-value: 0.0006-6 h), while 25\% CFS from the deletion mutant $S$. anginosus BSU $1211 \Delta$ blp 3 slightly enhances growth, when compared to medium without CFS. Furthermore, the activity of Angicin was evaluated in a bacterial survival assay. Since $25 \%$ CFS was the best concentration in the inhibition experiment, the same concentration was chosen for a survival assay. In this assay L. monocytogenes, L. grayi and L. ivanovii were investigated. An overnight culture of the indicated strains was inoculated freshly in the morning and grown to an O.D. ${ }_{600 \mathrm{~nm}}$ of 0.1 . To the same amount of bacteria, resuspended in phosphate buffer, either $25 \%$ of active or inactive CFS was added. The effect on L. monocytogenes was a tenfold reduction. The inhibition of L. ivanovii and L. grayi with a $10^{4}$-fold and $10^{6}$-fold reduction respectively was even more pronounced, in phosphate buffer supplemented with the CFS of S. anginosus BSU 1211 $\Delta$ blp3 no reduced survival could be seen (Fig. 6). In contrast, incubation with CFS of $S$. anginosus BSU 1211 significantly reduced the number of surviving cells (Fig. 6). In a next step, listerial cells treated with $25 \%$ CFS of S. anginosus BSU 1211 were analyzed via transmission electron microscopy to investigate the mechanism of action of Angicin. Pictures were thoroughly screened for loss of membrane integrity (Fig. 6). For L. monocytogenes more damaged cells can be seen in the treated group than in the control group. Numbers of intact L. ivanovii cells also seem decreased after treatment with active CFS for 15 min and a lot of cell debris can be seen. Especially for L. grayi membrane disruption is visible in samples treated with active CFS for $15 \mathrm{~min}$. Multiple cells appear lysed and loss of membrane integrity often seems to appear at sites of division. None of these changes can be seen in control cells treated with CFS of S. anginosus BSU $1211 \Delta b l p 3$. 


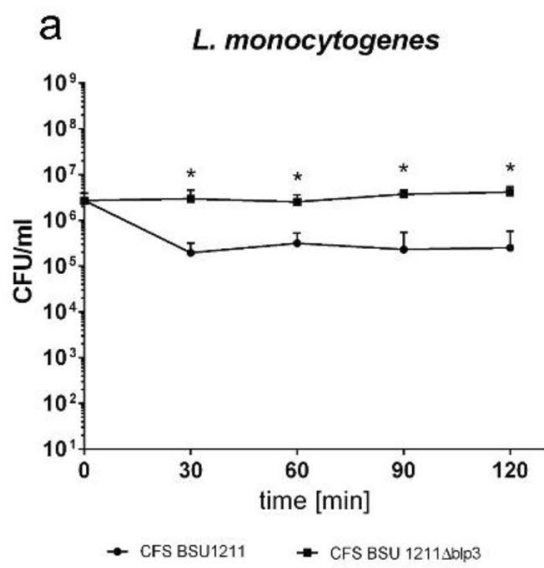

CFS BSU $1211 \Delta b l p 3$

b

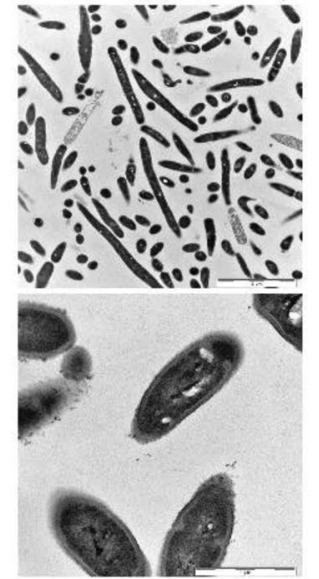

C

L. ivanovii

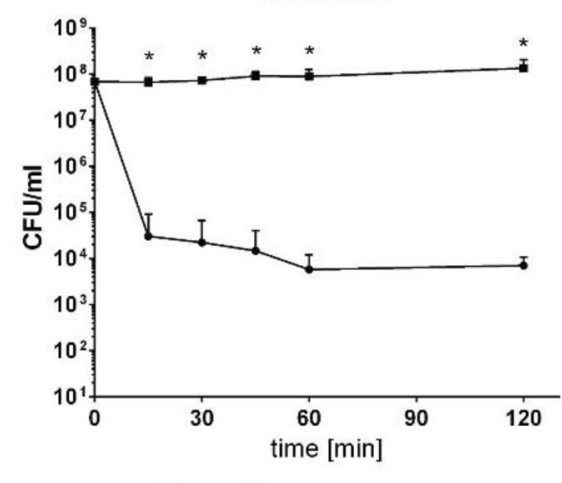

- CFS BSU1211 $\quad$ - CFS BSU $1211 \Delta \mathrm{blp} 3$

$$
\text { e }
$$

L. grayi

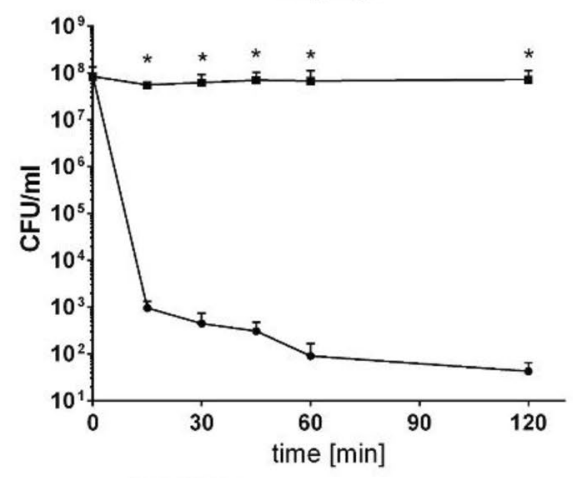

$\rightarrow$ CFS BSU $1211 \rightarrow$ CFS BSU $1211 \Delta b / p 3$ d

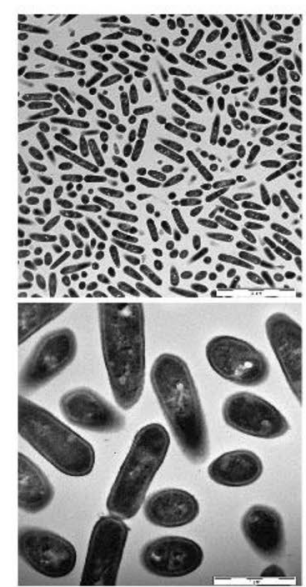

f

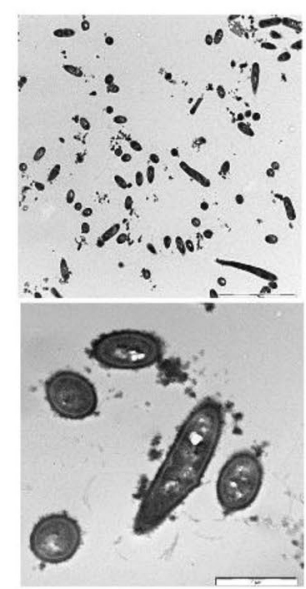

CFS BSU 1211
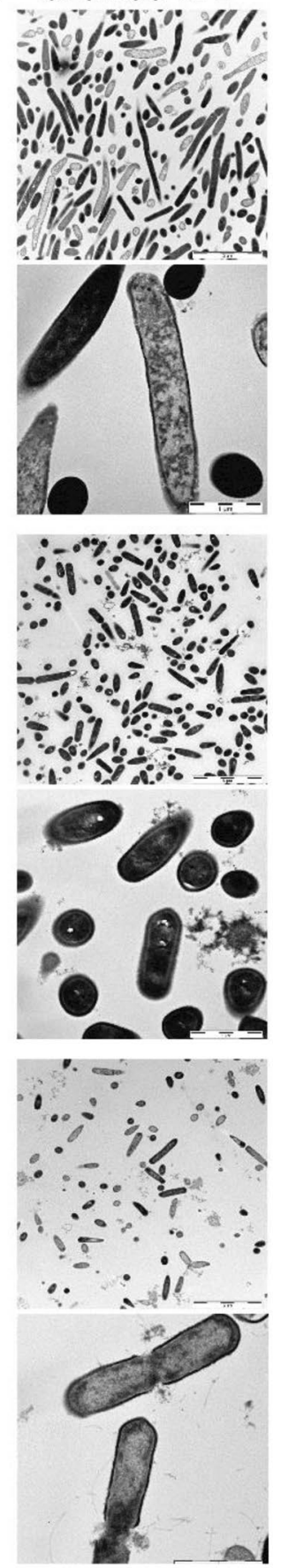

Figure 6. Effect of cell-free supernatant (CFS) of S. anginosus BSU 1211 or S. anginosus BSU $1211 \Delta$ blp 3 on Listeria monocytogenes, L. ivanovi and L. grayi. Survival of L. monocytogenes (a), L. ivanovi (c), L. grayi (e) in the presence of $25 \%$ CFS of S. anginosus BSU 1211 or S. anginosus BSU $1211 \Delta$ blp 3 over a time course of $2 \mathrm{~h}$. Transmission electron microscopy (TEM) pictures of L. monocytogenes cells (b) treated with 25\% CFS of $S$. anginosus BSU 1211 or S. anginosus BSU $1211 \Delta b l p 3$ for $2 \mathrm{~h}$ at $37^{\circ} \mathrm{C}$. TEM pictures of $L$. ivanovi (d) and $L$. grayi (f) were done after 15 min incubation with either $25 \%$ CFS of S. anginosus BSU 1211 or S. anginosus BSU $1211 \Delta$ blp3. Depicted for the survival assay is the mean + standard deviation of five independent experiments. TEM experiments were conducted once. Scale bar of the upper images is $5 \mu \mathrm{m}$, scale bar of the lower images represents $1 \mu \mathrm{m}$. Significant differences in survival were calculated with a Mann-Whitney- $U$-test $\left({ }^{*} \mathrm{p}<0.05\right)$. 


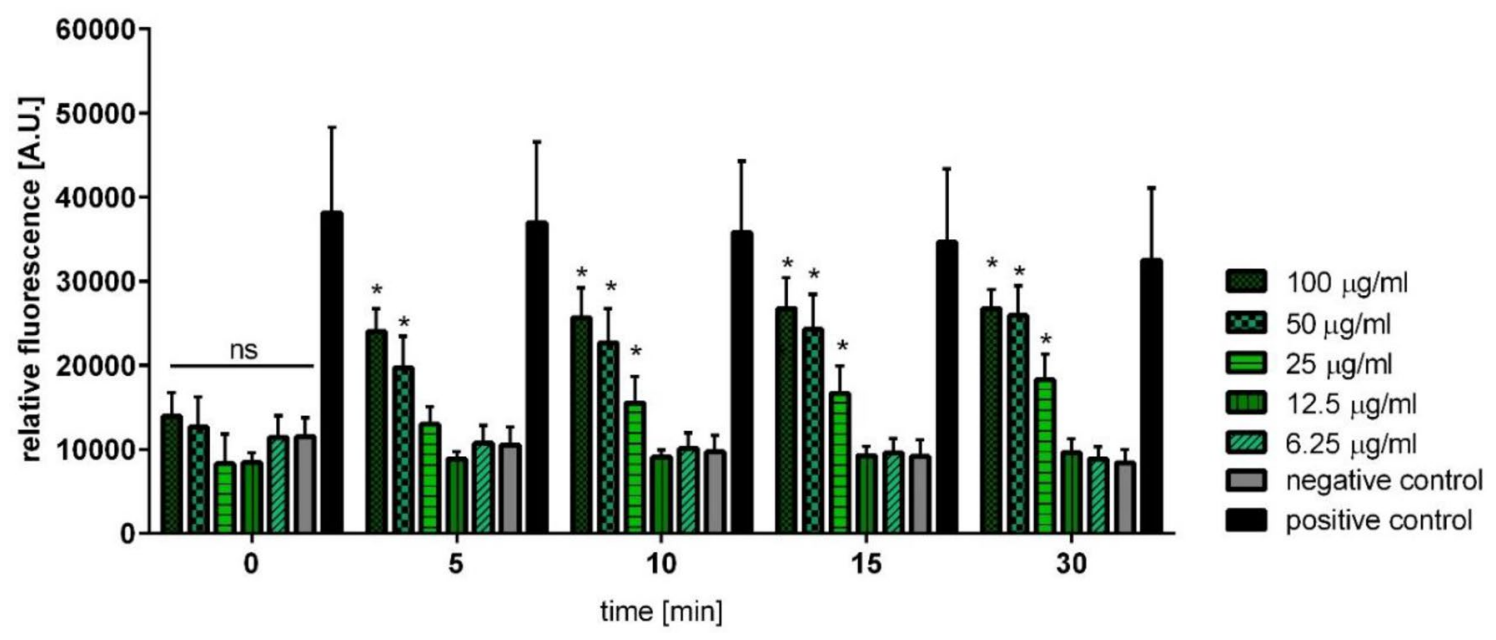

Figure 7. Effect of Angicin on membrane integrity of L. monocytogenes. Bacterial cells were incubated with different Angicin concentrations for $1 \mathrm{~h}$ at $37^{\circ} \mathrm{C}$ and fluorescence was detected using Tecan Plate Reader (Excitation: $488 \mathrm{~nm}$; Emission: $530 \mathrm{~nm}$ ) at the indicated time points. $6.05 \mu \mathrm{g} / \mathrm{ml}$ Angicin equal a concentration of $1 \mu \mathrm{M}$ Angicin. L. monocytogenes treated with $70 \%$ Ethanol was used as positive control. Depicted are five independent experiments conducted with three technical replicates. Statistically significant differences to the negative control were calculated with Mann-Whitney- $U$ test $\left({ }^{*} \mathrm{p}<0.05\right)$.

Mechanism of action. The most common mode of action of bacteriocins is membrane permeabilization. To investigate this mechanism in the context of Angicin treatment a SYTOX Green Membrane Permeabilization Assay was conducted. SYTOX Green is a fluorescent DNA stain that can enter the bacterial cell after membrane disruption. Therefore, the fluorescence intensity is an indicator of membrane integrity. Treating L. monocytogenes with 100,50 or $25 \mu \mathrm{g} / \mathrm{ml}$ synthetic Angicin lead to a significant SYTOX enrichment, indicating membrane disruption of the target cells (Fig. 7). Already after 5 min of incubation with either 100 or $50 \mu \mathrm{g} /$ $\mathrm{ml}$ synthetic Angicin the membrane is significantly disrupted, indicating a very fast mechanism of action of the peptide (p-value: 0.0079). Additionally, no significant difference between the ethanol treated cells (positive control) and cells treated with $100 \mu \mathrm{g} / \mathrm{ml}$ of Angicin for $15 \mathrm{~min}$ can be detected.

Immunity proteins. For self-protection bacteriocin producers express immunity proteins. To explore, if Blp3.3 protein represents as predicted an immunity protein, a functional assay was performed. The gene $b l p 3.3$ was introduced into plasmid pAT28 under the control of an endogenous promotor or without a promotor and transformed into the Angicin sensitive target strains S. anginosus SK52 and S. constellatus BSU 1213. In a next step a one-layer RDA was performed and the effect of $S$. anginosus BUS 1211 on the target strains was determined. Inhibition zones of mutants were compared to inhibition zones of the wildtype strain harboring empty pAT28 plasmid. Transformation of S. anginosus SK52 with blp3.3 under the control of an endogenous promotor led to a significantly reduced sensitivity towards Angicin (Fig. 8). Whereas blp3.3 without promoter did not alter inhibition zone sizes. Comparable results were obtained for the S. constellatus strain BSU 1213. Introducing the blp3.3 gene with an endogenous promotor led to significantly decreased inhibition zones. However, introducing blp3.3 alone into S. constellatus BSU 1213 had no significant effect. In summary, this data supports a role of Blp3.3 in immunity against Angicin.

Subsequently, Blp3.3 protein was recombinantly expressed in E. coli and purified to investigate its effect on the antimicrobial activity of Angicin. To that end, we preincubated Blp3.3 together with Angicin for $1 \mathrm{~h}$ at $37^{\circ} \mathrm{C}$ before the Angicin activity was tested in a two-layer RDA. We found that Blp3.3 alone already caused a zone of inhibited growth (Supplementary Fig. S4a) and it did not decrease Angicin activity on the target strain L. monocytogenes, irrespective of whether we used equimolar, substoichometric or superstoichometric concentrations of Blp3.3. Moreover, recombinant Blp3.3 protein did not affect the inhibitory activity of S. anginosus BSU1211 against $L$. monocytogenes when analyzing the inhibition zone size in a one-layer RDA. In addition, there was no inhibition of L. monocytogenes by Blp3.3 protein with or without S. anginosus BSU $1211 \Delta b l p 3$ (Supplementary Fig. S4b).

\section{Discussion}

In their natural habitat, bacteria are part of complex multi-species environments. S. anginosus typically resides in the oral cavity which can be colonized with up to 700 different species ${ }^{34,35}$. Closely related species often need similar nutrients or inhabit a similar space, therefore there is an ongoing competition between these species. Secreting antimicrobial substances, like bacteriocins, provides the producing organism with a great colonization advantage $\mathrm{e}^{36,37}$.

Putative bacteriocin production of streptococcal species from the $S$. anginosus group has previously been reported $^{38,39}$. To elucidate the molecular background of this phenomenon, 95 S. anginosus strains were evaluated for inhibitory activity in coculture experiments, which led to the selection of strain BSU 1211 for its potent 
a

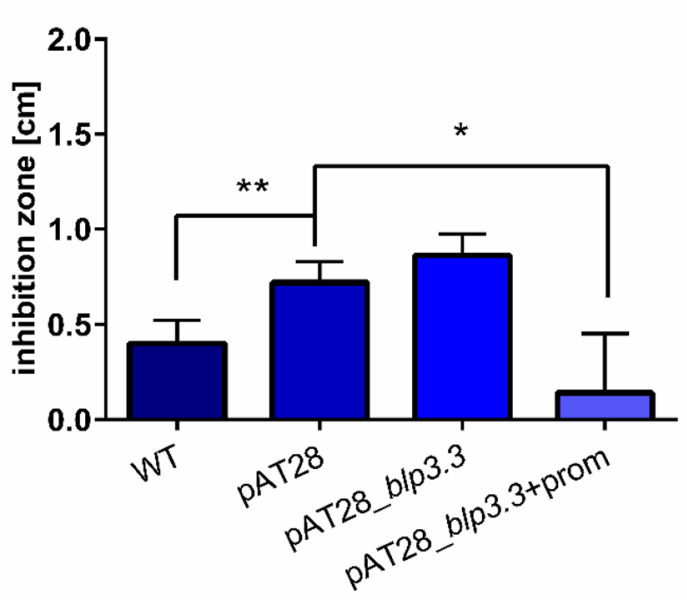

b

S. constellatus BSU 1213

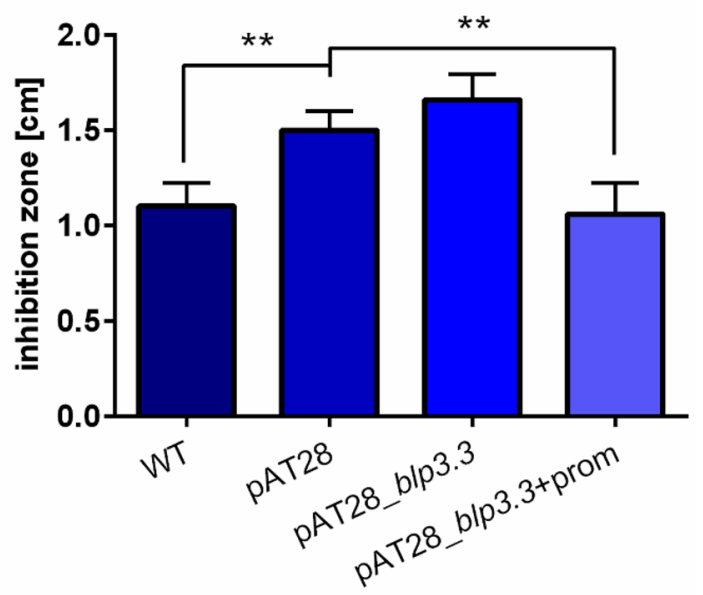

Figure 8. Influence of blp3.3 on inhibition zone diameters. Blp3.3 of S. anginosus BSU 1211 was transformed into susceptible target strains (a S. anginosus SK 52, b S. constellatus) either alone or under the control of an endogenous promotor. These mutants were used as target strains in a one-layer radial diffusion assay and tested against S. anginosus BSU 1211. Data was collected in at least five independent experiments. A significant difference to target strains transformed with the empty vector was tested with a Mann-Whitney- $U$-test $\left({ }^{*} \mathrm{p}<0.05,{ }^{* *} \mathrm{p}<0.01\right.$ and $\left.{ }^{* *} \mathrm{p}<0.001\right)$.

antimicrobial activity. In this strain the genetic basis of bacteriocin production and regulation was further investigated. Bacteriocin production is often regulated through quorum sensing systems ${ }^{40}$. In streptococci, like S. intermedius and S. pyogenes the sil system controls bacteriocin production ${ }^{12,17}$. A sil locus was also identified and predicted to be functional in many of the surveyed $S$. anginosus strains. In nearly all these strains inducing the sil two component system (SilAB) by addition of the autoinducing peptide SilCR $_{\mathrm{SAG}-\mathrm{C}}$, turns on bacteriocin production. In $S$. anginosus the sil locus is directly adjacent to putative bacteriocin genes, encoded in the blp3 region. By genetic mutagenesis we could show that this region is indeed responsible for bacteriocin production, since a complete deletion mutant of blp 3 was unable to inhibit the growth of any target strains. To identify the bacteriocin the three putative bacteriocin genes of this locus were mutated separately. A deletion of $b l p 3.1$ and blp3.6 did not alter bacteriocin activity, while deleting blp3.4 completely abolished the inhibitory effect. Interestingly, the deduced peptides of blp3.1 and blp3.6 both contain a GxxxG motif, which is a key feature of two peptide bacteriocins $\mathrm{s}^{29}$, that function only as a couple. Typically, the structural genes of two peptide bacteriocins are located directly next to each other. But this is not the case in the blp3 region of S. anginosus. It may be possible that due to this spatial gene separation no active bacteriocin can be formed. The putative bacteriocin region of SAG is a known hotspot of genetic diversity ${ }^{12}$. Possibly, the peptides are active when certain environmental conditions are met or other signals are present.

The identified S. anginosus bacteriocin was designated Angicin. The Angicin prepeptide is 84 amino acids long of which the first 30 amino acids form the leader peptide. Mature Angicin has a predicted pI of 10.2 and a molecular mass of $6053 \mathrm{Da}$. In our experiments Angicin showed a good antimicrobial activity against the Gram positive species S. anginosus, S. constellatus, L. monocytogenes, L. grayi, L. ivanovii and VRE. Moderate inhibitory activity could be observed against Gram negative microorganisms such as E. coli, K. pneumoniae, P. aeruginosa, A. baumannii. In some cases, spontaneous Angicin-resistant colonies of S. constellatus, L. monocytogenes and L. ivanovii appeared in the inhibition zones. In further studies, these resistant colonies could be genetically analyzed for mutations and thereby a putative receptor for Angicin might be identified ${ }^{23}$. The appearance of spontaneous bacteriocin-resistant mutants is documented for many bacteriocins $s^{41,42}$. This needs to be considered for further applications and to completely inhibit target organisms, often bacteriocins are not administered alone but in combination with other bacteriocins or antibiotics ${ }^{43,44}$.

Comparing peptide sequences, Angicin shows homology to Bovicin (variant 255) and is grouped into the Garvicin Q family which also includes BacSJ as a member ${ }^{22,45-47}$. Garvicin Q is a class IId bacteriocin of Lactococcus garvieae with a wide spectrum of activity. It is active against all tested strains of carnobacteria, enterococci, lactococci, leuconostoc and listeria and most of the tested Lactobacillus and Pediococcus strains. While all species of the genera Bacillus, Campylobacter, Staphylococcus and Streptococcus as well as P. aeruginosa, Salmonella typhimurium and Candida albicans are not susceptible ${ }^{23}$. BacSJ is produced by Lactobacillus paracasei and shows a very similar spectrum of activity with the only exception being a resistance of Lactococcus garvieae against BacSJ but not Garvicin $\mathrm{Q}^{22}$. Bovicin (variant 255), a bacteriocin first isolated from Streptococcus gallolyticus, shows only a narrow spectrum of activity with inhibitiory properties against E. faecium, Butyrivibrio fibrisolvens, Lactobacillus ruminis and Peptostreptococcus anaerobius. All Gram negative species as well as Streptococcus bovis, Bifidobacterium thermophilum or Ruminobacter amylophilus are insensitive towards the peptide ${ }^{47,48}$. In summary, Garvicin Q and BacSJ seem to be mainly important for intra- and interspecies competition. This may also be true for Angicin, which inhibits besides other S. anginosus isolates other streptococci, VRE and listeria. 
Bacteriocins mostly kill target cells by membrane permeabilization. The electrostatic interaction between the cationic peptide and the negatively charged bacterial membrane is important as well as amphiphilic structures ${ }^{49}$. However to function more efficiently bacteriocins usually utilize a receptor present in the bacterial membrane ${ }^{23,50}$. While for bovicin variant 255 no receptor is identified yet, it was proven that garvicinQ and BacJS target the IIC and IID components of the mannose phosphotransferase system (Man-PTS) ${ }^{22,23}$. The Man-PTS is described as a receptor for many bacteriocins, mainly the class IIa bacteriocins ${ }^{24}$. Due to sequence homology this gives rise to the question if Angicin might use the Man-PTS as a receptor as well. S. anginosus BSU 1211 is not able to inhibit Gram negative species and synthetic Angicin only shows an inhibition of Gram negative bacteria when administered at high concentrations. As already demonstrated for antibiotics, a reason for bacteriocin ineffectiveness against Gram negative species seems to be the outer membrane ${ }^{51,52}$. It inhibits an interaction between bacteriocin and its cognate receptor. Nisin binding to lipid II for example is inhibited by the outer membrane. However, inhibition of Gram negative species can be enhanced by the addition of chelating agents like ethylenediaminetetraacetic acid, that destroys the outer membrane ${ }^{53,54}$. For Angicin a similar situation may be the case.

Bacteriocins often kill target cells by membrane permeabilization. The electrostatic interaction between the cationic peptide and the negatively charged bacterial membrane is important as well as amphiphilic structures ${ }^{49}$. By a SYTOX Green membrane permeabilization assay it was demonstrated that Angicin leads to a disruption of the membrane in target cells. Already 5 min after Angicin treatment (Fig. 7) a significant difference in fluorescence signal to untreated cells is visible, indicating a fast mechanism of action. A rapid target cell lysis is not unusual and has also been observed in bacteriocins from enterococci and lactobacilli ${ }^{55,56}$. This data is supported by survival assays and TEM analysis, showing reduced cell numbers and rupture of membranes in listeria cells (Fig. 6). However, membrane permeabilization is mainly seen when high concentrations of Angicin are administered. For other bacteriocins it has been speculated that bacteriocins only work as membrane perturbers at concentrations that exceed what is present in a natural environment ${ }^{57}$. In lower or more natural concentrations, bacteriocin producers can use different mechanisms to inhibit competitors. Subtilisin for example interferes with quorum sensing of target organisms and thereby inhibits biofilm formation ${ }^{58}$. Thus, apart from membrane disruption other mechanisms may also play a role in the antibacterial activity of Angicin. For example, Garvicin A has been shown to interfere with cell division by inhibition of septum formation ${ }^{59}$. In CFS treated L. grayi cells loss of membrane integrity often appears at sites of division, which points in a similar direction. For the other listerial species, TEM experiments were not that clear. However, cells look damaged indicating that Angicin may harm target cells not only by membrane disruption but also other mechanisms.

Bacteriocin producers are rendered insensitive towards their own bacteriocin by simultaneous expression of immunity proteins ${ }^{60}$. Immunity proteins have a high specificity towards the bacteriocin and several different modes of action are already described, including loss of bacteriocin binding, sequestering, bacteriocin export or degradation of the bacteriocin ${ }^{61-64}$. By bioinformatic analysis of the $b l p 3$ region, $b l p 3.3$ was predicted as an immunity protein. It shows similarities to the immunity protein PisI, which protects against the class IIa bacteriocin piscolin $126^{65,66}$. Heterologous expression of blp3.3 in Angicin target strains led to a decreased sensitivity of these strains. Similar results were obtained for PisI as well as for other bacteriocins ${ }^{63,67,68}$. Already the introduction of the plasmid alone led to an increased sensitivity towards Angicin. Carrying a plasmid increases metabolic burdens on bacteria, often rendering them more sensitive to stress conditions ${ }^{69,70}$. A possible explanation why introduction of an empty plasmid alone may result in a higher sensitivity towards bacteriocins.

Immunity proteins may form a tertiary complex with the bacteriocin and the bacteriocin receptor ${ }^{67,71,72}$. Formation of this complex seems to depend on conformational changes after the initial binding of the bacteriocin to its receptor. Preincubation of Angicin with blp3.3 did not alter activity, implying that there is no direct interaction between these proteins, which further supports the theory of a tertiary complex. Immunity was increased but not complete upon heterologous expression of $b l p 3.3$, which may indicate the presence of a second immunity protein as it is the case for other bacteriocins ${ }^{73}$. Bagle 4 predicted $b l p 3.5$ as another immunity protein. Furthermore, a CAAX protease is present in the $b l p 3$ locus, representing another protein which may be involved in self-immunity against bacteriocins ${ }^{74}$.

Some bacteriocins like nisin, pediocin PA-1 and leucocin A are administered as food preservatives. Angicin inhibits L. monocytogenes, a species posing a major health risk for food safety ${ }^{75}$. For an application in food preservation, characteristics like stability over a wide $\mathrm{pH}$ and temperature range are important ${ }^{76}$. With remaining active in a pH ranging from 2 to 10 and at temperatures till $90^{\circ} \mathrm{C}$ both criteria are met by Angicin. Furthermore, Angicin shows activity against VRE, a pathogen posing a great health risk $^{33}$. VRE can cause infections like endocarditis, bacteremia and urinary tract infections and is one of the main causes of nosocomial infections ${ }^{77,78}$. Treatment options are limited and new ways to deal with this pathogen are needed ${ }^{79}$.

This is the first study describing and characterizing a bacteriocin of S. anginosus. The small cationically charged Angicin not only inhibits closely related species, but furthermore the important food pathogen $L$. monocytogenes and the clinically relevant vancomycin resistant E. faecium. This activity complemented with high thermal and wide $\mathrm{pH}$ stability render Angicin an interesting compound for food preservation and antimicrobial therapies.

\section{Methods}

Bacterial strains and growth conditions. All strains used in this study are summarized in Supplementary Table S3. Escherichia coli was cultivated in lysogeny broth (LB-Miller). E. coli EC101 and DH5a were hosts for plasmids pAT28 and pAT18. E. coli mutants were incubated in the presence of $100 \mu \mathrm{g} / \mathrm{ml}$ spectinomycin (pAT28) or $400 \mu \mathrm{g} / \mathrm{ml}$ erythromycin (pAT18). Liquid cultures were kept aerobically at $37^{\circ} \mathrm{C}$ on a shaker $(180 \mathrm{rpm})$, whereas plates were incubated at $37^{\circ} \mathrm{C}$ and $5 \% \mathrm{CO}_{2}$. All other used bacterial strains were cultivated on sheep blood agar plates, for liquid broth THY medium (Todd-Hewitt Broth supplemented with $0.5 \%$ yeast 
extract) was used. If necessary, streptococci were grown with $120 \mu \mathrm{g} / \mathrm{ml}$ spectinomycin or $10 \mu \mathrm{g} / \mathrm{ml}$ erythromycin, respectively. Plates as well as liquid cultures were incubated at $37^{\circ} \mathrm{C}$ and $5 \% \mathrm{CO}_{2}$.

General DNA techniques. Commercial kits, following the manufacturer's protocols were used to isolate DNA (GeneEluteTM Bacterial Genomic DNA, Sigma-Aldrich; QIAamp ${ }^{\oplus}$ DNA Mini Kit, Qiagen) or plasmids (QIAprep ${ }^{\oplus}$ Spin Miniprep Kit, Qiagen). Polymerase chain reaction (PCR) was conducted using standard protocols for Taq polymerase. Default settings for PCR were an initial denaturation at $95^{\circ} \mathrm{C}$ for $5 \mathrm{~min}$. Followed by 32 cycles of $1 \mathrm{~min}$ at $95^{\circ} \mathrm{C}, 30 \mathrm{~s}$ at $50^{\circ} \mathrm{C}, 1-3 \mathrm{~min}$ at $72{ }^{\circ} \mathrm{C}$ rounded up by a final elongation of $7 \mathrm{~min}$ at $72{ }^{\circ} \mathrm{C}$. For templates longer than 3000 bp the Expand Long Template PCR system: DNA pol. Mix was used. Clean up of PCR products was performed with NucleoSpin ${ }^{\star}$ Gel and PCR Clean-up (Machery-Nagel). Primers used in this study are listed in Supplementary Table S4. Commercial nucleotides sequencing was carried out by Eurofins Genomics (Ebersberg, Germany) and Microsynths Seqlab laboratories (Göttingen, Germany).

Sil and blp3 screen. For obtaining the sil and blp3 sequence information, primers were designed for this region based on the genome sequence of S. anginosus_1_2_62CV (Accession: KY315455.1). PCRs were performed on the chromosomal DNA of S. anginosus strains BSU 1211, BSU 1326, BSU 1370 and BSU 1401 using primer pairs $1 / 2,3 / 4$ or $3 / 7,5 / 6,8 / 9,10 / 17,11 / 16,12 / 13,14 / 15$. All PCR products were purified and sequenced. (Accession numbers: BSU 1211: MZ766502, BSU 1326: MZ766503, BSU 1370: MZ766504, BSU 1401: MZ766505). Screening for the presence of blp3.4 in 99 S. anginosus isolates was performed using primers $18 / 19$.

Radial diffusion assay. To measure bacteriocin activity, a modified radial diffusion assay (RDA) was conducted $^{80}$. For testing antagonism of bacteria against other bacteria a one-layer RDA was performed, whereas for investigating the antimicrobial activity of supernatant or peptides a two-layer RDA was done. In both cases, overnight cultures of target strains as well as putative bacteriocin producer strains (BPS) were centrifuged at $3000 \times g$ for $10 \mathrm{~min}$ and the pellet was solved in $10 \mathrm{mM}$ phosphate buffer. After repeated centrifugation at $3000 \times g$ for $10 \mathrm{~min}$ the pellet was reconstituted in $5 \mathrm{ml} 10 \mathrm{mM}$ phosphate buffer. Following O.D. $600 \mathrm{~nm}$ determination each plate was seeded with $2 \times 10^{7}$ bacterial cells of the target strains.

For a one-layer RDA bacterial cells were inoculated in still liquid Trypticase Soy Agar (Oxoid) and $20 \mathrm{ml}$ plates were poured. After solidification, holes were cut into the agar with sterile wide bore pipette tips (Axygena corning brand). These wells were filled with overnight cultures of putative BPS, which were adjusted to an O.D. $600 \mathrm{~nm}$ of 0.5 . Following overnight incubation at $37^{\circ} \mathrm{C}$ and $5 \% \mathrm{CO}_{2}$, inhibition zones were measured in $\mathrm{cm}$. In some assays $100 \mathrm{ng}$ of the autoinducing peptide SilCR $_{\text {SAG-C }}$ (GWLEDLFSPYFKKYKLGKLGQPDLG) were added simultaneously with the bacteria to test its effect on bacteriocin production. The peptide was synthesized by the Core facility of functional peptidomics (UPEP, Ulm University, Ulm, Germany) based on the deduced sequence of SilCR $\mathrm{SAG}_{\mathrm{A}-\mathrm{C}}$ of $\mathrm{S}$. anginosus strain BSU 1211. Purity levels of SilCR $\mathrm{SAG}_{\mathrm{C}}$ exceeded $95 \%$ and were determined via high performance liquid chromatography (HPLC).

To carry out a two-layer RDA bacterial cultures were inoculated in $15 \mathrm{ml}$ of still liquid $1 \%$ agarose and were poured into a petri dish. Wells were punched into the solidified agarose and filled with the test substance. After $3 \mathrm{~h}$ of aerobic incubation at $37^{\circ} \mathrm{C}$ an overlay with $10 \mathrm{ml}$ Trypticase Soy Agar was performed. Following solidification plates were incubated at $37^{\circ} \mathrm{C}$ and $5 \% \mathrm{CO}_{2}$ overnight. Inhibition zones were quantified in $\mathrm{cm}$. This assay was used to assess the antimicrobial activity of differently treated cell free supernatant (CFS). Furthermore, the peptide sequence of Angicin was deduced from the S. anginosus BSU 1211 DNA sequence. In a next step the 54 amino acid sequence without leader peptide (GSGYCKPVMVGANGYACRYSNGRWDYKVTKGIFQATTDVIVKGWAEYGPWIPRH) was synthesized by Peptide Specialty Laboratories GmbH (PSL GmbH, Heidelberg, Germany). Angicin was purified using HPLC and afterwards purity was analyzed with HPLC and MS-MALDI. The determined purity was $>98 \%$. The molecular mass was calculated at $6053.1 \mathrm{~g} / \mathrm{mol}$, thus $6.05 \mu \mathrm{g} / \mathrm{ml} \mathrm{equal}$ $1 \mu \mathrm{M}$. It was solved in ultra-pure water. The activity of this peptide was investigated via a two-layer RDA.

Construction of mutants. Construction of blp3.3 mutants. Based on the plasmid pAT28 two different $b l p 3.3$ constructs were created and cloned into E. coli EC101. One vector contained blp3.3 alone and a second vector encoded $b l p 3.3$ with its endogenous promoter (promblp3.3). Blp3.3 without promoter was amplified with primers $20 / 22$ and promblp3.3 with primers 21/22. All primers that were used introduced EcoRI and BamHI restriction sites, for cloning purposes. In a next step these constructs were transformed into $S$. anginosus strain SK52 and S. constellatus BSU 1213 by electroporation as described elsewhere ${ }^{81}$. In brief, bacterial cells were made competent by several washing steps in $10 \%$ glycerol. Then $1 \mu \mathrm{g}$ of plasmid DNA was added and cells were exposed to an electrical pulse. Clones were selected on THY-plates containing $120 \mu \mathrm{g} / \mathrm{ml}$ spectinomycin. Correct insertions were confirmed by nucleotide sequencing.

Construction of blp3 and angicin deletion mutants. A S. anginosus BSU $1211 \Delta b l p 3$ strain was created via splicing by overlap extension PCR (SOE) and competence related transformation as described in Bauer et al. ${ }^{21}$. In brief, blp3 flanking regions of $S$. anginosus BSU 1211 were amplified with primer pairs 23/24 for Fragment 1 (F1) and 25/26 for Fragment 2 (F2). The primers introduced an overlap to either a lox66 or a lox71 site. The spectinomycin resistance gene was amplified from pGA14-Spc with primers $27 / 28$, which also introduced a lox66 or lox71 site, respectively, adjacent to the spectinomycin gene. Thereby, an overlap of all fragments was achieved. All fragments were fused via SOE-PCR. Subsequently, the linear DNA construct was transformed into S. anginosus strain BSU 1211 by inducing natural competence with CSP- $1^{21}$. BSU 1211 was incubated with $100 \mathrm{ng}$ CSP-1 and after 40 min the DNA construct was added. After two hours of incubation bacteria were plated on 
THY-spectinomycin plates. To eliminate the spectinomycin resistance gene, spectinomycin positive clones were transformed with a cre-recombinase encoding plasmid (pAT18-cre-rec $\mathrm{tufA}_{\text {Af }}$ ), which recombines the two lox-sites to a singular lox72 site. By incubating the resulting clones without antibiotics, plasmid loss was induced to create a markerless deletion strain.

The same method was used for creating single gene deletion mutants of the $b l p 3$ region. For a deletion of blp3.1 primers 5/29 (F1) and 30/31 (F2), for blp3.4 primers $7 / 32$ (F1) and 33/3 (F2), for blp.3.6 primers 34/35 (F1) and 36/37 (F2) were used.

To control a successful transformation all constructs were sequenced therefore primers 1/5 (blp3) 38/39 (blp3.1), 40/41 (blp3.4) and 42/43 (blp3.6) were applied.

Complementation of S. anginosus BSU 1211 1 blp3. To complement the deletion mutant, S. anginosus BSU $1211 \Delta b l p 3$ was transformed with pAT18-blp3 by using the natural competence system as previously described ${ }^{21}$. The $b l p 3$ region was amplified using primers $44 / 45$ and cloned into pAT18. Transformed cells were plated on sheep blood agar plates containing $10 \mu \mathrm{g} / \mathrm{ml}$ erythromycin and incubated anaerobically at $37^{\circ} \mathrm{C}$.

Cell free supernatant (CFS). Putative bacteriocin producing strains were grown in THY supplemented with $10 \%$ FBS for $24 \mathrm{~h}$. After centrifugation for $30 \mathrm{~min}$ at $4{ }^{\circ} \mathrm{C}$ and either $4000 \times g(50 \mathrm{ml})$ or $11,900 \times g$ (UZ) $(350 \mathrm{ml})$ a sterile filtration was performed. Cell free supernatant (CFS) was precipitated with $35 \%$ Ammonium sulfate under stirring conditions for $1 \mathrm{~h}$ at $4{ }^{\circ} \mathrm{C}$. Following centrifugation for $30 \mathrm{~min}$, at $4{ }^{\circ} \mathrm{C}$ and $4000 \times g$ the supernatant was discarded and the pellet was resuspended in $10 \mathrm{mM}$ phosphate buffer in one tenth of the original culture volume. In a next step, samples were concentrated via $3 \mathrm{~K}$ filters (Amicon ${ }^{\circledR}$ Ultra Centrifugal Filters). The concentrate contained the active fraction of the peptide. CFS activity was afterwards tested via a two-layer radial diffusion assay.

Effect of environmental factors on angicin activity. The stability of bacteriocins was investigated in regard to $\mathrm{pH}$, temperature, degradation by enzymes and time. CFS was adjusted to $\mathrm{pH}$ values ranging from 2 to 10 . Following overnight incubation at the adjusted $\mathrm{pH}$ at room temperature (RT), $\mathrm{pH}$ was neutralized and the CFS tested for antibacterial activity. Furthermore, CFS was incubated at $40,60,80,90^{\circ} \mathrm{C}$ for $1 \mathrm{~h}$ or at 90 and $100{ }^{\circ} \mathrm{C}$ for $30 \mathrm{~min}$. After cooling down to RT activity was measured. To assess bacteriocin degradation either proteinase K (Sigma) or Lipase of Aspergillus niger (Sigma) was added to CFS to a final concentration of one $\mathrm{mg} / \mathrm{ml}$ and incubated for $1 \mathrm{~h}$ at $37^{\circ} \mathrm{C}$. After inactivation of the enzymes for $1 \mathrm{~h}$ at $70^{\circ} \mathrm{C}$ and cooling to RT antimicrobial activity was quantified. To further assess stability at low temperatures CFS was stored at $4{ }^{\circ} \mathrm{C},-20^{\circ} \mathrm{C}$ and $-70^{\circ} \mathrm{C}$ for one year and then inhibitory activity was analyzed. Activity of $50 \mu \mathrm{g} / \mathrm{ml}$ Angicin was tested after incubation at 60,80 and $90^{\circ} \mathrm{C}$ for $1 \mathrm{~h}$. Furthermore, treatment of $5 \mu \mathrm{g} / \mathrm{ml}$ Angicin with $1 \mathrm{mg} / \mathrm{ml}$ lipase or proteinase $\mathrm{K}$ was conducted and afterwards activity was tested. All measurements were carried out in triplicate. If the test compound was inactive and not used as a control only two independent experiments were conducted.

Determination of minimal inhibition concentration. The O.D. $600 \mathrm{~nm}$ of an overnight culture of $L$. monocytogenes and L. grayi was determined and adjusted to 0.1 in Müller-Hinton broth and afterwards diluted 1:4. $5 \mu \mathrm{l}$ of this bacterial solution were mixed with $95 \mu \mathrm{l}$ of Angicin ranging in concentrations from 100 to $0.0122 \mu \mathrm{g} / \mathrm{ml}$. After $24 \mathrm{~h}$ incubation at $37^{\circ} \mathrm{C}$ and 5\% $\mathrm{CO}_{2}$ O.D. $600 \mathrm{~nm}$ was determined.

Inhibition assay. In a 96-well plate a serial dilution of CFS from either S. anginosus BSU 1211 or the deletion mutant was prepared in THY broth ranging from 100\% CFS to 6.25\%. THY broth without CFS supplementation served as control. $5 \mu \mathrm{l}$ of target bacteria, adjusted to an O.D. $600 \mathrm{~nm}$ of 0.1 , were added to each well in a final volume of $100 \mu \mathrm{l}$. The plate was incubated at $37^{\circ} \mathrm{C}$ and $5 \% \mathrm{CO}_{2}$ for $24 \mathrm{~h}$. Absorbance $600 \mathrm{~nm}$ was measured every hour for $9 \mathrm{~h}$ and after $24 \mathrm{~h}$ in a Tecan microplate reader $\mathrm{M}$ infinite 200. At least five independent experiments were conducted. Measurements were done in triplicates.

Survival assay. An overnight culture of L. monocytogenes, L. ivanovii or L. grayi was diluted to an O.D. $600 \mathrm{~nm}$ of 0.02 in $10 \mathrm{ml}$ THY. When an O.D. ${ }_{600} \mathrm{~nm}$ of 0.1 was reached, $1 \mathrm{ml}$ was transferred to a $1.5 \mathrm{ml}$ Eppendorf tube and centrifuged at $8800 \times g$ for $2 \mathrm{~min}$. The supernatant was discarded and the pellet reconstituted in $750 \mu 10 \mathrm{mM}$ phosphate buffer with 10\% Tryptic Soy broth (TSB). $250 \mu \mathrm{l} \mathrm{CFS} \mathrm{of} \mathrm{either} \mathrm{S.} \mathrm{anginosus} \mathrm{BSU} 1211$ or S. anginosus BSU $1211 \Delta b l p 3$ was added and mixed. Cells were incubated at $37^{\circ} \mathrm{C}$ and after $0 \mathrm{~h}, 30 \mathrm{~min}, 1 \mathrm{~h}$ and $2 \mathrm{~h}$ serial dilutions were performed and plated on THY. After overnight incubation at $37^{\circ} \mathrm{C}$ and $5 \% \mathrm{CO}_{2}$ colony forming units per $\mathrm{ml}$ were determined. At least five independent experiments were performed with technical duplicates.

Electron microscopy. Transmission electron microscopy was performed to investigate the effect of active CFS on target bacteria. Therefore, overnight cultures of target bacteria (S. constellatus, L. monocytogenes, L. ivanovii and L. grayi) were adjusted to an O.D. ${ }_{600 \mathrm{~nm}}$ of 0.02 and grown to an O.D. ${ }_{600 \mathrm{~nm}}$ of 0.1 and then $1 \mathrm{ml}$ was transferred into a $1.5 \mathrm{ml}$ Eppendorf tube and centrifuged at $8800 \times \mathrm{g}$ for $2 \mathrm{~min}$. The pellet was resuspended in $750 \mu \mathrm{l} 10 \mathrm{mM}$ phosphate buffer with 10\% TSB. 25\% (250 $\mu \mathrm{l})$ CFS from either the S. anginosus BSU 1211 or S. anginosus BSU $1211 \Delta$ blp 3 were added and subsequently incubated at $37^{\circ} \mathrm{C}$. S. constellatus and L. monocytogenes were incubated with CFS for $2 \mathrm{~h}$. In contrast, L. grayi and L. ivanovii were only incubated for $15 \mathrm{~min}$, since killing of target cells happend very fast. After centrifugation at $8800 \times g$ for 2 min the supernatant was removed. Cells were reconstituted in $40 \mu 10 \mathrm{mM}$ phosphate buffer with $10 \% \mathrm{TSB}$. Then $40 \mu \mathrm{l}$ of double concentrated fixing solution was added, consisting of 3.5\% glutharaldehyde, $1 \%$ Saccharose in phosphate buffer). 
Afterwards samples were postfixed in osmium tetroxide, dehydrated in a graded series of propanol, embedded in Epon, and ultrathin sectioned according to standard procedures. Samples were analyzed with a Jeol 1400 Transmission Electron Microscope. At least 20 images per sample were taken. Experiment was conducted once.

Recombinant expression of the immunity protein Blp3.3. Blp3.3 protein was recombinantly expressed in Escherichia coli RV308. The coding region of Blp3.3 was synthesized (Eurofins) and cloned to the C terminus of a 11 His-tagged maltose-binding protein in a pMAL-C5X vector (New England Biolabs) separated by a cleavage site for tobacco etch virus protease. Protein expression was performed in mineral salt medium M9 by addition of $1 \mathrm{mM}$ IPTG. Protein purification was done in eight steps: (1) amylose resin high flow (New England Biolabs) chromatography using a step elution from 0 to $10 \mathrm{mM}$ maltose in Tris buffer A (20 mM Tris/ $\mathrm{HCl}, \mathrm{pH} 7.5,200 \mathrm{ml} \mathrm{NaCl}$ ), (2) Ni Sepharose fast flow resin (GE Healthcare) chromatography using a step elution from 50 to $200 \mathrm{mM}$ Imidazol in Tris buffer B $(20 \mathrm{mM}$ Tris/ $\mathrm{HCl}, \mathrm{pH} 8.0,150 \mathrm{mM} \mathrm{NaCl})$, (3) fusion protein cleavage by overnight incubation with tobacco etch virus protease at $34{ }^{\circ} \mathrm{C}$, (4) Ni Sepharose fast flow resin chromatography to separate Blp3.3 from the fusion protein and maltose-binding protein, (5) Source 15 RPC resin (GE Healthcare) chromatography using a linear gradient from 0 to $86 \%(\mathrm{v} / \mathrm{v})$ of acetonitrile in $0.1 \%(\mathrm{v} / \mathrm{v})$ trifluoroacetic acid, (6) lyophilization with an alpha 2-4 LD plus freeze dryer (Christ) and redissolving in Tris buffer B, (7) Superdex 75 resin (GE Healthcare) chromatography using an isocratic elution in Tris buffer B and (8) Source 15 RPC resin chromatography (same condition as 5). The purified Blp3.3 was lyophilized and stored at $-80^{\circ} \mathrm{C}$ until further use. The chemical identity of Blp3.3 was verified by electrospray ionisation mass spectrometry. The determined monoisotopic mass $(11,247.0 \mathrm{Da})$ corresponds well to the theoretical monoisotopic mass expected from the amino acid sequence $(11,246.9 \mathrm{Da})$.

SYTOX green membrane permeabilization assay. A SYTOX Green Membrane Permeabilization Assay was used to assess the effect of synthesized Angicin against L. monocytogenes. Therefore, an overnight culture was adjusted to an O.D. ${ }_{600 \mathrm{~nm}}$ of 0.05 and incubated at $37^{\circ} \mathrm{C}$ and $5 \% \mathrm{CO}_{2}$ till an O.D. $600 \mathrm{~nm}$ of 0.1 was reached. One $\mathrm{ml}$ of the bacterial culture was transferred into an Eppendorf tube and centrifugation at 10,000 $\times g$ for 2 mins followed. The pellet was solved in one volume of $10 \mathrm{mM}$ phosphate solution with $0.2 \mu \mathrm{M}$ Sytox (Invitrogen). $90 \mu \mathrm{l}$ of the bacteria-Sytox solution were mixed with Angicin with final concentrations ranging from 100 to $6.25 \mu \mathrm{g} / \mathrm{ml}$. A Tecan microplate reader M infinite 200 reader was used to measure fluorescence intensity. Excitation/Emission wavelength were $488 / 530 \mathrm{~nm}$, respectively. Cells treated with $70 \%$ Ethanol for five minutes were used as positive control. Measurements were performed in triplicates and in five independent measurements.

Bioinformatic and statistical analysis. As a source for nucleotide sequences the GenBank database (http://www.ncbi.nlm.nih.gov/) was used. Homology searches were conducted using Basic Local Alignment Search Tool (http://www.ncbi.nlm.nih.gov/Blast/) ${ }^{82}$. For further genetic investigations SnapGene 5.0 (https:// www.snapgene.com/) was accessed. Genetic alignments were done using CLC Main Workbench v7.7.3 (http:// www.clcbio.com) with default settings (gap open cost value 10.0, gap extension cost value 1.0). Bioinformatical analysis of the $b l p 3$ region was done with Bagel4 (http://bagel4.molgenrug.nl/) ${ }^{83}$. Analysis of Angicin peptide sequence was performed with Bachem (https://www.bachem.com/service-support/peptide-calculator/). Endogenous promotor search was carried out with Softberry-BPROM (http://www.softberry.com/berry.phtml?topic= bprom\&group=programs\&subgroup=gfindb). GraphPad Prism V6 was used to create graphs and do statistical analysis. If not otherwise specified, all experiments were conducted independently at least five times. Experiments with inactive compounds were repeated at least twice. Depicted is always mean \pm standard deviation.

Received: 14 September 2021; Accepted: 1 December 2021

Published online: 21 December 2021

\section{References}

1. Poole, P. M. \& Wilson, G. Occurrence and cultural features of Streptococcus milleri in various body sites. J. Clin. Pathol. 32, 764-768 (1979).

2. Whiley, R. A., Beighton, D., Winstanley, T. G., Fraser, H. Y. \& Hardie, J. M. Streptococcus intermedius, Streptococcus constellatus, and Streptococcus anginosus (the Streptococcus milleri group): Association with different body sites and clinical infections. J. Clin. Microbiol. 30, 243-244 (1992).

3. Laupland, K. B., Ross, T., Church, D. L. \& Gregson, D. B. Population-based surveillance of invasive pyogenic streptococcal infection in a large Canadian region. Clin. Microbiol. Infect. 12, 224-230 (2006).

4. Jiang, S. et al. Clinical characteristics of infections caused by Streptococcus anginosus group. Sci. Rep. 10, 9032 (2020).

5. Kobo, O., Nikola, S., Geffen, Y. \& Paul, M. The pyogenic potential of the different Streptococcus anginosus group bacterial species: Retrospective cohort study. Epidemiol. Infect. 145, 3065-3069 (2017).

6. Reissmann, S. et al. Contribution of Streptococcus anginosus to infections caused by groups $\mathrm{C}$ and $\mathrm{G}$ streptococci, southern India. Emerg. Infect. Dis. 16, 656-663 (2010).

7. Sibley, C. D. et al. McKay agar enables routine quantification of the 'Streptococcus milleri' group in cystic fibrosis patients. J. Med. Microbiol. 59, 534-540 (2010).

8. Siegman-Igra, Y., Azmon, Y. \& Schwartz, D. Milleri group streptococcus-a stepchild in the viridans family. Eur. J. Clin. Microbiol. Infect. 31, 2453-2459 (2012).

9. Kurm, V. et al. Competition and predation as possible causes of bacterial rarity. Environ. Microbiol. 21, 1356-1368 (2019).

10. Alvarez-Sieiro, P., Montalbán-López, M., Mu, D. \& Kuipers, O. P. Bacteriocins of lactic acid bacteria: Extending the family. Appl. Microbiol. Biotechnol. 100, 2939-2951 (2016).

11. Arnison, P. G. et al. Ribosomally synthesized and post-translationally modified peptide natural products: Overview and recommendations for a universal nomenclature. Nat. Prod. Rep. 30, 108-160 (2013). 
12. Mendonca, M. L. et al. The sil locus in Streptococcus anginosus group: Interspecies competition and a hotspot of genetic diversity. Front. Microbiol. 7, 2156 (2016).

13. Miller, E. L. et al. Eavesdropping and crosstalk between secreted quorum sensing peptide signals that regulate bacteriocin production in Streptococcus pneumoniae. ISME J. 12, 2363-2375 (2018).

14. Ni, J. et al. Autoregulation of lantibiotic bovicin HJ50 biosynthesis by the BovK-BovR two-component signal transduction system in Streptococcus bovis HJ50. Appl. Environ. Microbiol. 77, 407-415 (2011).

15. Shanker, E. \& Federle, M. J. Quorum sensing regulation of competence and bacteriocins in Streptococcus pneumoniae and mutans. Genes 8, 15 (2017).

16. Barbour, A., Philip, K. \& Muniandy, S. Enhanced production, purification, characterization and mechanism of action of salivaricin 9 lantibiotic produced by Streptococcus salivarius NU10. PLoS ONE 8, e77751 (2013).

17. Hertzog, B. B. et al. A sub-population of group A Streptococcus Elicits a population-wide production of bacteriocins to establish dominance in the host. Cell Host Microbe 23, 312-323.e6 (2018).

18. Soto, C., Padilla, C. \& Lobos, O. Mutacins and bacteriocins like genes in Streptococcus mutans isolated from participants with high, moderate, and low salivary count. Arch. Oral Biol. 74, 1-4 (2017).

19. Mignolet, J. et al. Circuitry rewiring directly couples competence to predation in the gut dweller Streptococcus salivarius. Cell Rep. 22, 1627-1638 (2018).

20. Wholey, W.-Y., Kochan, T. J., Storck, D. N. \& Dawid, S. Coordinated bacteriocin expression and competence in Streptococcus pneumoniae contributes to genetic adaptation through neighbor predation. PLOS Pathog. 12, e1005413 (2016).

21. Bauer, R., Mauerer, S., Grempels, A. \& Spellerberg, B. The competence system of Streptococcus anginosus and its use for genetic engineering. Mol. Oral Microbiol. https://doi.org/10.1111/omi.12213 (2017).

22. Tymoszewska, A., Walczak, P. \& Aleksandrzak-Piekarczyk, T. BacSJ-another bacteriocin with distinct spectrum of activity that targets man-PTS. Int. J. Mol. Sci. 21, 7860 (2020).

23. Tymoszewska, A., Diep, D. B., Wirtek, P. \& Aleksandrzak-Piekarczyk, T. The non-lantibiotic bacteriocin garvicin Q targets man-pts in a broad spectrum of sensitive bacterial genera. Sci. Rep. 7, 8359 (2017).

24. Ramnath, M., Arous, S., Gravesen, A., Hastings, J. W. \& Héchard, Y. Expression of mptC of Listeria monocytogenes induces sensitivity to class IIa bacteriocins in Lactococcus lactis. Microbiology 150, 2663-2668 (2004).

25. Belotserkovsky, I. et al. Functional analysis of the quorum-sensing streptococcal invasion locus (sil). PLoS Pathog. 5, e1000651 (2009).

26. Hidalgo-Grass, C. et al. A locus of group A Streptococcus involved in invasive disease and DNA transfer. Mol. Microbiol. 46, 87-99 (2002).

27. Founou, R. C., Founou, L. L. \& Essack, S. Y. Clinical and economic impact of antibiotic resistance in developing countries: A systematic review and meta-analysis. PLoS ONE 12, e0189621 (2017).

28. Mulani, M. S., Kamble, E. E., Kumkar, S. N., Tawre, M. S. \& Pardesi, K. R. Emerging strategies to combat ESKAPE pathogens in the era of antimicrobial resistance: A review. Front. Microbiol. 10, 539 (2019).

29. Nissen-Meyer, J., Oppegård, C., Rogne, P., Haugen, H. S. \& Kristiansen, P. E. Structure and mode-of-action of the two-peptide (class-IIb) bacteriocins. Probiotics Antimicrob. Proteins 2, 52-60 (2010).

30. Bogaardt, C., van Tonder, A. J. \& Brueggemann, A. B. Genomic analyses of pneumococci reveal a wide diversity of bacteriocins: Including pneumocyclicin, a novel circular bacteriocin. BMC Genomics 16, 554 (2015).

31. Hossain, M. S. \& Biswas, I. Mutacins from Streptococcus mutans UA159 are active against multiple streptococcal species. Appl. Environ. Microbiol. 77, 2428-2434 (2011).

32. Ovchinnikov, K. V. et al. Novel group of leaderless multipeptide bacteriocins from gram-positive bacteria. Appl. Environ. Microbiol. 82, 5216-5224 (2016).

33. Remschmidt, C. et al. Continuous increase of vancomycin resistance in enterococci causing nosocomial infections in Germany: 10 years of surveillance. Antimicrob. Resist. Infect. Control 7, 54 (2018).

34. Aas, J. A., Paster, B. J., Stokes, L. N., Olsen, I. \& Dewhirst, F. E. Defining the normal bacterial flora of the oral cavity. J. Clin. Microbiol. 43, 5721-5732 (2005).

35. Paster, B. J., Olsen, I., Aas, J. A. \& Dewhirst, F. E. The breadth of bacterial diversity in the human periodontal pocket and other oral sites. Periodontol. 2000(42), 80-87 (2006).

36. Dawid, S., Roche, A. M. \& Weiser, J. N. The blp bacteriocins of Streptococcus pneumoniae mediate intraspecies competition both in vitro and in vivo. Infect. Immun. 75, 443-451 (2007).

37. Kommineni, S. et al. Bacteriocin production augments niche competition by enterococci in the mammalian gastrointestinal tract. Nature 526, 719-722 (2015).

38. Drucker, D. B. \& McKillop, C. M. Bacteriocin production by Streptococcus milleri. Can. J. Microbiol. 28, 278-283 (1982).

39. Willcox, M. D. \& Drucker, D. B. Partial characterisation of the inhibitory substances produced by Streptococcus oralis and related species. Microbios 55, 135-145 (1988).

40. García-Curiel, L., del Rocío López-Cuellar, M., Rodríguez-Hernández, A. I. \& Chavarría-Hernández, N. Toward understanding the signals of bacteriocin production by Streptococcus spp. and their importance in current applications. World J. Microbiol. Biotechnol. 37, 15 (2021).

41. Cotter, P. D. An 'Upp'-turn in bacteriocin receptor identification: Identifying bacteriocin receptors. Mol. Microbiol. 92, 1159-1163 (2014)

42. Harris, L. J., Fleming, H. P. \& Klaenhammer, T. R. Sensitivity and resistance of Listeria monocytogenes ATCC 19115, Scott A, and UAL500 to Nisin. J. Food Prot. 54, 836-840 (1991).

43. Schillinger, U., Chung, H.-S., Keppler, K. \& Holzapfel, W. H. Use of bacteriocinogenic lactic acid bacteria to inhibit spontaneous nisin-resistant mutants of Listeria monocytogenes Scott A. J. Appl. Microbiol. 85, 657-663 (1998).

44. Mathur, H. et al. Bacteriocin-antimicrobial synergy: A medical and food perspective. Front. Microbiol. 8, 1205 (2017).

45. Lozo, J. et al. Molecular characterization of a novel bacteriocin and an unusually large aggregation factor of Lactobacillus paracasei subsp. paracasei BGSJ2-8, a natural isolate from homemade cheese. Curr. Microbiol. 55, 266-271 (2007).

46. Tosukhowong, A. et al. Garvieacin Q, a novel class II bacteriocin from Lactococcus garvieae BCC 43578. Appl. Environ. Microbiol. 78, 1619-1623 (2012).

47. Whitford, M. F., McPherson, M. A., Forster, R. J. \& Teather, R. M. Identification of bacteriocin-like inhibitors from rumen Streptococcus spp. and isolation and characterization of bovicin 255. Appl. Environ. Microbiol. 67, 569-574 (2001).

48. Cookson, A. L., Noel, S. J., Kelly, W. J. \& Attwood, G. T. The use of PCR for the identification and characterisation of bacteriocin genes from bacterial strains isolated from rumen or caecal contents of cattle and sheep. FEMS Microbiol. Ecol. 48, 199-207 (2004).

49. Vasilchenko, A. S. \& Valyshev, A. V. Pore-forming bacteriocins: structural-functional relationships. Arch. Microbiol. 201, 147-154 (2019).

50. Kjos, M. et al. Sensitivity to the two-peptide bacteriocin lactococcin G is dependent on UppP, an enzyme involved in cell-wall synthesis. Mol. Microbiol. 92, 1177-1187 (2014).

51. Cao-Hoang, L., Marechal, P. A., Le-Thanh, M. \& Gervais, P. Synergistic action of rapid chilling and nisin on the inactivation of Escherichia coli. Appl. Microbiol. Biotechnol. 79, 105-109 (2008).

52. Heesterbeek, D. A. C. et al. Complement-dependent outer membrane perturbation sensitizes Gram-negative bacteria to Grampositive specific antibiotics. Sci. Rep. 9, 3074 (2019). 
53. Li, Q., Montalban-Lopez, M. \& Kuipers, O. P. Increasing the antimicrobial activity of nisin-based lantibiotics against gram-negative pathogens. Appl. Environ. Microbiol. 84, 12 (2018).

54. Stevens, K. A., Sheldon, B. W., Klapes, N. A. \& Klaenhammer, T. R. Nisin treatment for inactivation of Salmonella species and other gram-negative bacteria. Appl. Environ. Microbiol. 57, 3613-3615 (1991).

55. Chakchouk-Mtibaa, A. et al. Safety aspect of Enterococcus faecium FL31 strain and antibacterial mechanism of its hydroxylated bacteriocin BacFL31 against Listeria monocytogenes. BioMed Res. Int. 2018, 1-10 (2018).

56. Wayah, S. B. \& Philip, K. Characterization, yield optimization, scale up and biopreservative potential of fermencin SA715, a novel bacteriocin from Lactobacillus fermentum GA715 of goat milk origin. Microb. Cell Factories 17, 972 (2018).

57. Chikindas, M. L., Weeks, R., Drider, D., Chistyakov, V. A. \& Dicks, L. M. Functions and emerging applications of bacteriocins. Curr. Opin. Biotechnol. 49, 23-28 (2018).

58. Algburi, A. et al. Subtilosin prevents biofilm formation by inhibiting bacterial quorum sensing. Probiotics Antimicrob. Proteins 9 , 81-90 (2017).

59. Maldonado-Barragïn, A. et al. Garvicin A, a novel class IId bacteriocin from Lactococcus garvieae that inhibits septum formation in L. garvieae strains. Appl. Environ. Microbiol. 79, 4336-4346 (2013).

60. Fimland, G., Eijsink, V. G. H. \& Nissen-Meyer, J. Comparative studies of immunity proteins of pediocin-like bacteriocins. Microbiology 148, 3661-3670 (2002).

61. Alkhatib, Z., Abts, A., Mavaro, A., Schmitt, L. \& Smits, S. H. J. Lantibiotics: How do producers become self-protected?. J. Biotechnol. 159, 145-154 (2012).

62. de Bastos, M. C. F., Coelho, M. L. V. \& da Santos, O. C. S. Resistance to bacteriocins produced by Gram-positive bacteria. Microbiol. Read. Engl. 161, 683-700 (2015).

63. Johnsen, L., Fimland, G., Mantzilas, D. \& Nissen-Meyer, J. Structure-function analysis of immunity proteins of pediocin-like bacteriocins: C-terminal parts of immunity proteins are involved in specific recognition of cognate bacteriocins. Appl. Environ. Microbiol. 70, 2647-2652 (2004).

64. Nawrocki, K. L., Crispell, E. K. \& McBride, S. M. Antimicrobial peptide resistance mechanisms of gram-positive bacteria. Antibiot. Basel Switz. 3, 461-492 (2014).

65. Gursky, L. J. et al. Production of piscicolin 126 by Carnobacterium maltaromaticum UAL26 is controlled by temperature and induction peptide concentration. Arch. Microbiol. 186, 317-325 (2006).

66. Jack, R. W. et al. Characterization of the chemical and antimicrobial properties of piscicolin 126, a bacteriocin produced by Carnobacterium piscicola JG126. Appl. Environ. Microbiol. 62, 2897-2903 (1996).

67. Diep, D. B., Skaugen, M., Salehian, Z., Holo, H. \& Nes, I. F. Common mechanisms of target cell recognition and immunity for class II bacteriocins. Proc. Natl. Acad. Sci. USA. 104, 2384-2389 (2007).

68. Martin-Visscher, L. A., Sprules, T., Gursky, L. J. \& Vederas, J. C. Nuclear magnetic resonance solution structure of PisI, a group $\mathrm{B}$ immunity protein that provides protection against the type IIa bacteriocin piscicolin 126, PisA. Biochemistry 47, 6427-6436 (2008).

69. Glick, B. R. Metabolic load and heterologous gene expression. Biotechnol. Adv. 13, 247-261 (1995).

70. Sato, T. \& Kuramitsu, H. Plasmid maintenance renders bacteria more susceptible to heat stress. Microbiol. Immunol. 42, 467-469 (1998).

71. Barraza, D. E. et al. New insights into enterocin CRL35: Mechanism of action and immunity revealed by heterologous expression in Escherichia coli. Mol. Microbiol. 105, 922-933 (2017).

72. Ríos Colombo, N. S., Chalón, M. C., Navarro, S. A. \& Bellomio, A. Pediocin-like bacteriocins: New perspectives on mechanism of action and immunity. Curr. Genet. 64, 345-351 (2018).

73. Draper, L. A., Ross, R. P., Hill, C. \& Cotter, P. D. Lantibiotic immunity. Curr. Protein Pept. Sci. 9, 39-49 (2008).

74. Kjos, M., Snipen, L., Salehian, Z., Nes, I. F. \& Diep, D. B. The abi proteins and their involvement in bacteriocin self-immunity. J. Bacteriol. 192, 2068-2076 (2010).

75. Allerberger, F. \& Wagner, M. Listeriosis: a resurgent foodborne infection. Clin. Microbiol. Infect. 16, 16-23 (2010).

76. Perez, R. H., Zendo, T. \& Sonomoto, K. Novel bacteriocins from lactic acid bacteria (LAB): Various structures and applications. Microb. Cell Factories 13(Suppl 1), S3 (2014).

77. Raza, T., Ullah, S. R., Mehmood, K. \& Andleeb, S. Vancomycin resistant Enterococci: A brief review. JPMA J. Pak. Med. Assoc. 68, 768-772 (2018).

78. Zhang, Y., Du, M., Chang, Y., Chen, L. \& Zhang, Q. Incidence, clinical characteristics, and outcomes of nosocomial Enterococcus spp. bloodstream infections in a tertiary-care hospital in Beijing, China: a four-year retrospective study. Antimicrob. Resist. Infect. Control 6, 73 (2017).

79. Khan, H. A., Ahmad, A. \& Mehboob, R. Nosocomial infections and their control strategies. Asian Pac. J. Trop. Biomed. 5, 509-514 (2015).

80. Maricic, N. \& Dawid, S. Using the overlay assay to qualitatively measure bacterial production of and sensitivity to pneumococcal bacteriocins. J. Vis. Exp. https://doi.org/10.3791/51876 (2014).

81. Ricci, M. L., Manganelli, R., Berneri, C., Orefici, G. \& Pozzi, G. Electrotransformation of Streptococcus agalactiae with plasmid DNA. FEMS Microbiol. Lett. 119, 47-52 (1994).

82. Altschul, S. F., Gish, W., Miller, W., Myers, E. W. \& Lipman, D. J. Basic local alignment search tool. J. Mol. Biol. 215, 403-410 (1990).

83. van Heel, A. J. et al. BAGEL4: a user-friendly web server to thoroughly mine RiPPs and bacteriocins. Nucleic Acids Res. 46, W278W281 (2018).

\section{Acknowledgements}

RB, BS, PW and MF are supported by the German Research Foundation (DFG) within the CRC 1279, subprojects A02 and A03. Work of GMS was supported by the Novo Nordisk Fonden within the framework of the Fermentation-based Biomanufacturing Initiative (FBM) (FBM-Grant: NNF17SA0031362). VV thanks the International Graduate School in Molecular Medicine Ulm for the support. We thank M. Wunderlin (Service center mass spectrometry, Ulm University) for mass spectrometric analysis of Blp3.3. The authors like to express thanks to Prof. Dr. Riedel, the national reference center for streptococci at RWTH Aachen University, University Hospital Düsseldorf and INSTAND e.V. for providing microorganisms.

\section{Author contributions}

V.V., R.B. and B.S. designed this study. V.V. and S.M. conducted the experiments. N.S. and C.H. expressed Blp3.3 under the supervision of M.F. G.S. helped designing experiments to get active cell free supernatant. PW helped in the preparation and analysis of TEM samples. V.V. and B.S. analyzed the results. V.V. wrote and B.S. reviewed this manuscript. 


\section{Funding}

Open Access funding enabled and organized by Projekt DEAL.

\section{Competing interests}

The authors declare no competing interests.

\section{Additional information}

Supplementary Information The online version contains supplementary material available at https://doi.org/ 10.1038/s41598-021-03797-5.

Correspondence and requests for materials should be addressed to B.S.

Reprints and permissions information is available at www.nature.com/reprints.

Publisher's note Springer Nature remains neutral with regard to jurisdictional claims in published maps and institutional affiliations.

(c) (i) Open Access This article is licensed under a Creative Commons Attribution 4.0 International License, which permits use, sharing, adaptation, distribution and reproduction in any medium or format, as long as you give appropriate credit to the original author(s) and the source, provide a link to the Creative Commons licence, and indicate if changes were made. The images or other third party material in this article are included in the article's Creative Commons licence, unless indicated otherwise in a credit line to the material. If material is not included in the article's Creative Commons licence and your intended use is not permitted by statutory regulation or exceeds the permitted use, you will need to obtain permission directly from the copyright holder. To view a copy of this licence, visit http://creativecommons.org/licenses/by/4.0/.

(C) The Author(s) 2021 